Article

\title{
Is Innovation a Driver of Sustainability? An Analysis from a Spanish Region
}

\author{
Alicia Llorca-Ponce ${ }^{1, *(\mathbb{D}}$, Gregorio Rius-Sorolla ${ }^{1}\left(\mathbb{D}\right.$ and Francisco J. Ferreiro-Seoane ${ }^{2}(\mathbb{D}$ \\ 1 Departamento de Organización de Empresas, Universitat Politècnica de València, Camino de Vera, s/n, \\ 46022 Valencia, Spain; greriuso@upv.es \\ 2 Department of Applied Economics, Faculty of Law, Faculty of Social Sciences, University of Santiago Compostela, \\ Avda. Ángel Echeverri, s/n, Campus Vida, 15782 Santiago Compostela, Spain; franciscojesus.ferreiro@usc.es \\ * Correspondence: alllopon@omp.upv.es
}

check for updates

Citation: Llorca-Ponce, A.;

Rius-Sorolla, G.; Ferreiro-Seoane, F.J.

Is Innovation a Driver of

Sustainability? An Analysis from a

Spanish Region. Sustainability 2021,

13, 9286. https://doi.org/10.3390/

su13169286

Academic Editor: Agustín Alvarez

Received: 13 May 2021

Accepted: 15 August 2021

Published: 18 August 2021

Publisher's Note: MDPI stays neutral with regard to jurisdictional claims in published maps and institutional affiliations.

Copyright: (C) 2021 by the authors. Licensee MDPI, Basel, Switzerland. This article is an open access article distributed under the terms and conditions of the Creative Commons Attribution (CC BY) license (https:// creativecommons.org/licenses/by/ $4.0 /)$.

\begin{abstract}
Background. It is well-known that innovation contributes to economic growth, improves productivity and enables competitive advantage. However, beyond these matters, it would be of interest to know what role innovation plays in relation to sustainability. This paper focuses on whether innovation is a driver of sustainability in its three dimensions: social, economic and environmental. 2. Methods. The study was conducted with companies in the Valencian community (Spain) to analyze whether they significantly contribute to sustainability as innovators. Economical sustainability was assessed based on economic and financial profitability; social sustainability was assessed by employment generation. To determine whether companies contributed to environmental sustainability, we considered those which, apart from a reputation ("label") in innovation, had some kind of environmental certification. 3. Results. Our results indicate that innovative companies are more profitable and generate more employment. However, there are no differences in terms of performance and employment generation between innovative companies and those that are also environmentally sensitive. 4. Conclusion. Innovation is a driving force of economic and social sustainability in the studied area, but environmental sensitivity is not a driver for economic and social sustainability.
\end{abstract}

Keywords: innovation; driver; sustainability

\section{Introduction}

Schumpeter [1] highlights the importance of companies constantly innovating and generating changes in market as a method to ensure their survival and to create wealth. If innovation was already a crucial aspect of the dynamic civil society of the last century, today, it is essential for companies' survival. Nowadays, organizations are characterized by being dynamic, innovative and strategical. They are also expected to oriented toward fulfilling economic, social and environmental objectives. Therefore, companies sustainably manage their actions on a daily basis, which is mostly a fundamental methodological process [2]. The need to innovate is even greater in a globalized world, which has led to emerging new opportunities and challenges for companies, but which often leaves traditional barriers like territory or company size in the background. In this new context, the traditional role of governments has also been affected, and it is increasingly difficult to act in isolation from the rest of the world [3]. This new circumstance, characterized by a constantly changing environment, forces companies to innovate and to work in a new way, where stakeholders become increasingly important in their activities, especially in sustainability terms [3].

Companies need to continuously innovate to be competitive in the market, which requires the intervention of both internal factors and external agents.

The ability to innovate has become an absolute must for companies to compete. Achieving competitiveness depends on internal tangible and intangible resources and 
variables. Marketing strategies, the ability to access markets and innovation generate competitiveness [4]. According to Freeman "innovation is the process of integrating existing technology and inventions to create or improve a product, process or system" [5]. According to Drucker "Innovation is the specific tool of entrepreneurship, whether in an established company, a public institution or a new company" [6]. It is the means by which entrepreneurs create new wealth-generating resources or it endows existing resources with a higher potential to create wealth. Hence innovative entrepreneurship does not refer to a firm's size or age, but to a type of activity. At the core of this activity lies innovation: the effort to introduce a particular change that focuses on an enterprise's economic or social potential.

The aims of this article are to develop and test the hypothesis of whether innovation is a driver of sustainable development. Innovative enterprises were identified as those with the innovative enterprise "label" according to the Spanish Ministry of Science and Innovation. A Spanish area, Comunidad Valenciana (Valencian Community), which is large enough to be studied, was selected for this work and a statistical analysis was applied to extrapolate our conclusions. Our focus lay on small- and medium-sized enterprises (SME), which represent more than $99 \%$ of European enterprises, and $90 \%$ of the world's companies, produce around $60 \%$ of overall manufacturing and services turnover, and employ almost 70\% of the European and world workforce [7-9]. Their contribution to pollution is estimated at $60-70 \%$ of the world's pollution [10], and some experiences suggest that environmental support programs do not work with SMEs, given lack of related knowledge and time to implement them [11]. SMEs are those enterprises that meet the following three characteristics: they employ fewer than 250 persons, have an annual turnover that does not exceed 50 million euros and/or their total annual balance sheet does not exceed 43 million euros [12]. SMEs play an important role in the transformations needed for their transition to sustainable growth [13]. They must be innovative and adopt new technologies so that innovation becomes the engine of their development, in order to be competitive and grow sustainably [8].

The remainder of the paper is structured as follows: first, a theoretical framework is presented; second, the employed objectives and methods are presented; third, the qualitative study is discussed; finally, some conclusions and future works are provided.

\section{Theoretical Framework}

The following section begins by reviewing the concept of innovation and its implications for growth, and then moves on to sustainability. The implications of both for an economy and/or territory of the economy as well as for the organization are analyzed. Finally, the role of innovation as a driver towards sustainability is addressed. For this purpose, the narrative review has been combined with the systematic review of the literature [14]. In the case of the systematic review, the following steps were followed. Firstly, the Web of Science was used as database for the search, and the last five years was the time criterion by which articles that analyzed innovation as a driver for sustainability in SME were selected, with the search code of "TS = ("SME" AND sustain* AND innov*)", a total of 309 articles.

\subsection{Innovation as a Concept}

The literature that has dealt with the relation between innovation and countries and regions' economic progress and development is long-standing $[1,5,15,16]$. In the most fundamental sense, there are only two ways for an economy to grow in the long run. One is by increasing the quantity of inputs, and the other is by following new ways of using the number of available inputs [17]. Abramovitz was the first to attempt to measure or elucidate the extent to which long-run growth is due to these factors [17,18]. His study focused on the United States during the period between the end of the 19th century and the first half of the 20th century. He concluded that the growth factor could only explain $15 \%$ of the growth of the economy's output and the remaining $85 \%$ was explained by other 
causes, such as the way resources were used. Work along these lines was not undertaken again until the 1960s, when several studies addressed the relation between inputs and economic growth, and reached the same conclusion: a very large part of economic growth could not be explained by the growth factor [17]. Robert Solow [19] investigated economic growth and also found that economic growth could not be explained by the growth factor. It was precisely a very high residual value that led him to look for causes of growth beyond the growth factor.

Innovation is a significant contributor to business performance and success [20]. The benefits that innovation brings by making production processes more efficient, increasing information and knowledge processing or improving people's life quality, do not depend solely on new technology inventors, but are largely due to creativity in defining new products for users [17].

Today "from a macroeconomic point of view there is no doubt that innovations have a positive impact on growth and employment" [21]. A consensus has been reached about innovation being a key business success aspect [22], and it is "the most important factor in increasing a company's profitability" [23]. Innovation is recognized as a means for growth and development. "It, therefore, offers opportunities to directly address poverty, inequality and environmental sustainability" [24].

According to the European Central Bank [25] "one of the greatest benefits of innovation is its contribution to growth. Innovation makes it possible to increase productivity, i.e., to produce more with the same resources. When productivity increases, more goods and services are produced and the economy grows". Innovation is presently considered one of the basic factors of advanced countries' development and is linked with economic progress through the creation of more productive new product ideas and new operation methods than currently exist [26]. For a company, taking an innovative attitude allows it to develop its values and attitudes, and to promote ideas and projects, which improve its efficiency [27].

Since 1992, the Oslo Manual has been the international reference standard for conceptualizing and measuring innovation [26]. It is understood as the conception and implementation of significant changes in the company's product, process, marketing or organization to improve results. This manual prioritizes research and development $(R$ and $\mathrm{D}$ ) as a determining element in innovation processes and recognizes the importance of nontechnological factors for boosting firms' innovative capacity. A large part of innovation comes from qualified personnel, relationships with other organizations and an organizational structure that fosters learning and knowledge [28]. According to Corma [29] "innovation is the conversion of ideas and knowledge into improved products, processes or services for the market, thus satisfying the needs of citizens, businesses and public administrations". Innovation is the generation of new ideas that are used in several business activity areas (production of goods and services, relationships with suppliers, customers and employees, administrative processes, product attributes, distribution systems, etc.) and, thanks to these new ideas, companies' profitability increases [30]. Innovation is doing things that have not been done before, or doing things that have been done before by new methods-i.e., creating something new of commercial value. Innovation is a human action that is intentional and guided by economical and ethical values, such as freedom, equality, and environmental and social justice [31].

Innovation represents a pathway by which knowledge is transferred and converted into a process, product or service that incorporates new advantages for the market or society [32]. Innovation is objective, a goal, aspiration, a pragmatic reason, a value and commitment to change [33]. The $\mathrm{R}$ and $\mathrm{D}$ aim promotes the education-innovation-research triangle [34].

Innovation can bring new vitality to enterprises and is their main economic growth driver. Technological development has led the production of goods and services to greatly increase, and to higher income and welfare levels. However, economic growth has had a significant environmental impact. Since the 1970s, awareness about the negative effects 
that economic growth and prosperity have had on the environment has grown. While innovation has enabled, and continues to enable, economic growth and social progress, only recently have environmental concerns been brought to many industries' attention [35].

Thus, the kind of innovation needed to achieve sustainable development, based on the three economical, social and environmental development pillars, requires generating new ideas that contribute not only to wealth generation, but also to environmental quality and social progress. All this requires new steps and changes to transform standard innovation [36].

When innovation takes the sustainability perspective approach, emphasis should be placed on responsible innovation, to provide solutions to global natural resource degradation, climate change, economical progress and social well-being challenges, which is a type of innovation that is incipient in industry, and in SME to a greater extent [37].

Furthermore, the term innovation has been often linked with technology, and it should be noted that innovation is not only generated by technological development. Innovation can be generated from the variation of organizational structures by combining or generating plans for different services/products, or from a composition of marketing strategies with technological and traditional applications, to cover the respective segments of each organization [38]. Now, innovation is widely recognized as not only a set of fundamental resources for creating greater competitive advantage, but also as a business strategy to achieve higher levels of growth and performance by enabling companies to move more closely to sustainability [1,39-41]. The only way for companies to be competitive, and consequently for countries to grow, is to develop and improve our standard of living by creating new innovation-generated knowledge [42].

Firms are key players in innovation activities, as they are responsible for transforming acquired knowledge into innovative products and bringing them to the market. Today, as firms need to be competitive at all times, they must have up-to-date techniques and technologies that can be internally developed, obtained from $\mathrm{R}$ and $\mathrm{D}$ service providers or acquired from goods that already include them.

The Oslo Manual stresses the importance of identifying the qualities of firms comprising a region as a whole and the importance of cooperation between them, because this allows the regional innovation system to function more efficiently, thanks to the greater concentration of firms [43]. Firms in the Valencian Community, our study area, have low innovative content. In innovation terms, it is an intermediate region and not an advanced one, and its business areas are dominated by firms belonging to traditional industries with a low degree of technological intensity. Moreover, the number of companies in the sectors most-related to new technologies is small [44].

The barriers and drivers to SMEs' environmental involvement can be identified in both internal stakeholders (i.e., owners, staff, others) and external stakeholders (the government, agencies, environmental management organizations, financial institutions, customers, suppliers, the local community, the general public). These drivers can be grouped into commitment, motivation, knowledge, resources and legislation [11]. Governments can provide support through a combination of incentives, information, training and legislation. The set of policies that support business innovation has been reoriented toward taxation rather than as direct support instruments [45]. For R and D and technological innovations, Spain offers reductions in corporate income tax and rebates on employer social security contributions, introduced by Royal Decree 475/2014 of 13 June, only for R and D-intensive SMEs, recognized as such by having the official "Innovative SME" label [46].

\subsection{Sustainability Concept}

Although the sustainability concept originated in the 17th and 18th centuries, it did not emerge in a global sense until the 20th century [47]. In 1972, Rome's Club published "Limits to Growth", known as the Meadows Report [48]. This publication concludes that population and production cannot grow indefinitely, as some factors limit this expansion, such as progressive resources depletion and pollution. In the same year, several publi- 
cations appeared that highlighted this problem. From a development perspective, the sustainable development concept emerged and began to be shaped in the years following World War II. In the 1950s, development in the Western world was largely identified with growth, leading to unlimited increases in production and income. It was from the late 1960s and 1970s onward, when approaches and positions questioning the prevailing view, based on continuous growth, began to take hold. These decades saw the publication and popularization of works like Carson's "Silent Spring" [49], Ehrlich's "The Population Bomb" [50] and The Ecologist's "A Plan for Survival" [51] which, together with media coverage of ecological catastrophes, raised global awareness about the negative effects of the current growth model on the environment.

Beyond growth effects on the environment, awareness about growing social inequalities and the need to work on development has grown, and placed more emphasis on solving social problems beyond those of production growth. Development became more related to progress; indicators that focused more on social aspects, such as basic needs or and unemployment and poverty levels, began to be used. The 1972 UN Conference on the Human-Environment, in Stockholm, marked the first global summit to consider human impacts on the environment [47].

In 1987 the UN World Commission on the Environment and Development published its report "Our Common Future", known as the Brundtland Report, in which economical development implied economical growth which, at the same time, had to be socially and economically sustainable. It is now known that caring for the environment, more specifically environmental degradation reduction and resource depletion, can be achieved to a greater extent by poverty reduction and, for this to happen, countries must economically grow [52]. These approaches give way to the sustainable development concept, based on its three economical, social and environmental pillars.

In principle, the origins of the "three pillars" paradigm are attributed to the Brundtland Report, specifically Agenda 21, and the 2002 World Summit on Sustainable Development, but there seems to be no clear theoretical basis for the origin of either the concept or the model $[47,53]$. In any case, the three sustainable development pillars are an attempt to reconcile different inherent aspects of development that have become apparent in previous decades: trade-offs among economical growth, poverty reduction and inequalities, and environmental degradation. As the three-pillar vision is consolidated, sustainable development is understood as development that must balance three broad objectives to maintain economical growth, while protecting the environment and achieving social progress.

In 1997, Elkington published his popular book "Cannibals With Forks", with which he set out his "triple bottom line" (TBL) model, a translation of the three sustainable development pillars to the business environment [54]. The 'bottom line' of a corporation is complimented by bottom lines for socio-environmental performance, "termed 'people, planet, profit', encouraging firms to consider longer-term perspectives in their decision making" $[9,54]$. Although the model has been criticized for being vague and confusing, Elkington's TBL has become popular in the business world. "The three basic lines can never be considered in total isolation". "The three pillars are typically connected with each other in practice in ways involving such positive synergies" [55]. The economic bottom line focuses on an entity's financial aspect, such as "sales growth, profit growth, return on equity, return on asset and gearing" [56]. Social bottom-line sustainability includes employees, consumers and the host community [9,57]. Thus, the economic dimension measures the financial performance of an entity, while the other two dimensions require the entity to leverage its profits for the community, including social welfare and the prevention of environmental damage [58].

The environment has become more financially, socially and environmentally volatile, which has led to sustainability becoming a term, and a key issue, since the beginning of this century. Sustainability is not some kind of moral luxury to which companies must submit by social mandate; it is a way of working that reduces risk and contributes to generating more wealth for all actors in the long run. Sustainable supply chains, in all three 
economical, social and environmental dimensions, means reduced risk. A supplier's bad practices can seriously impact a customer, in either image or business terms. A customer with abusive labor practices is at higher risk of being left without supply due to a strike, just as a supplier with bad financial practices can suddenly go bankrupt and leave the customer without supply [59].

\subsection{Measuring Sustainability}

First, economical sustainability refers to the organization's ability to manage its resources and to generate long-term profitability. In this paper, economical sustainability was analyzed based on two performance analysis ratios: economical and financial profitability. The value of these ratios for "Innovative SME" was compared to the total number of SMEs in the Valencian Community, forming the comparison group. Economical profitability was obtained as a ratio of pre-tax profits over total assets. Financial profitability was obtained as a ratio of pre-tax profits over equity capital.

Second, according to the United Nations Global Compact, social sustainability is "about identifying and managing business impacts, both positive and negative, on people," "Directly or indirectly, companies affect what happens to employees, workers in the value chain, customers and local communities, and it is important to manage impacts proactively" [60]. In this paper, job creation by time was used as a variable to measure social sustainability, given the understanding that the capacity to generate employment in a territory contributes to strengthening and increasing the population's well-being. Social and environmental sustainability, in relation to management, appears to be related to corporate social responsibility (CSR), and is seen to contribute to social justice and to develop human rights [61]. There are many CSR concepts, of which the one recently put forward by the European Community [62] involves the "responsibility of enterprises for their impact on society". As a prerequisite, it implies respect for the law and collective bargaining agreements. CSR can be defined as a company's commitment to its stakeholders and society at large [3]. It implies companies' voluntary integration of social and environmental concerns into their business operations and their relationships with their stakeholders. It involves contributing to sustainable development, safety, health and social well-being, respecting and implementing local and international regulations, by taking into account stakeholders' interests and expectations, and maintaining ethical behavior and integrity, as well as transparency, in their management.

Third, environmental sustainability assessments must go beyond complying with legal obligations or symbolic integration [63]. Environmentally sustainable companies are expected to follow the guidelines of the ISO14000 series (Environmental Management Systems) or the typically used EMAS label (Eco-Management and Audit Scheme) [64]. The EMAS label was developed by the European Commission for companies and other organizations to assess, report and improve their environmental performance [65]. In Spain, 971 companies are certified with the EMAS label (7 April 2021), with only 11 in Alicante, four in Castellón and 33 in Valencia [65], which are the three provinces forming the Valencian Community. Moreover, other sector-specific guidelines like EN15804 (Sustainability in Construction) or Directive 2009/128/EC (alternative techniques to reduce dependence on the use of pesticides) should identify this environmental sustainability. Other sectors employ different indicators of their environmental performance. For example, the HIGG ${ }^{\circledR}$ Self-Assessment Index of the clothing-and-footwear industry is employed to assess environmental and social sustainability along the supply chain [66]. This index allows the textile industry to assess the environmental impact of its production activity [67]. The B Corp ${ }^{\circledR}$ movement [68] is an international community with more than 3200 companies committed to their social statutes to consider workers, the community and the environment, in a binding way, during their decision-making, so that companies become a regenerative force for society and the planet. Both propose a method to help SME to incorporate sustainability into their business model [69]. The international textile testing institutes association of Oeko-Tex ${ }^{\circledR}$ has been certifying textile products free of harmful substances (Standard 100) 
since 1992. During its evolution, it has incorporated social and environmental sustainability certifications into textile and leather production (STep, Sustainable Textile \& Leather Production) [70]. The ISSOP ${ }^{\circledR}$ seal of Sustainable Energy and Innovation without Programmed Obsolescence Foundation, which identifies those organizations with a firm commitment to excellence in the sustainability field, respects the environment and people without obsolescence [71]. The elimination of planned obsolescence implies that communities prioritize environmental, social and economical sustainability [72]. According to their companies' websites, all of them have been used to evaluate being environmentally sensitive as a measurement of an enterprise's environmental sustainability with the innovation label.

While sustainability in large business organizations has been widely discussed in the literature in recent years [73] the same does not seem to be true for SMEs. Compared with large companies, small companies are constrained by a lack of resources to invest in technology or human resource capacity to anticipate ecological impact $[74,75]$ or operation resources [76]. Obstacles that prevent SMEs from developing environmentally friendly include limited financial resources, the type of organizational structure and limited training on environmental issues $[15,77-80]$.

\subsection{Innovation as a Driver of Sustainability}

From the theoretical framework, several studies have related innovation to the business world and territory with positive effects. There are works on innovation linked with business development, such as Corsi et al. [81], which point out the positive effect of organizational innovation on companies' sales and productivity growth with a sample study of 4125 Spanish companies. Another notable work is that by Montégu et al. [82], which found a correlation between competition and innovation after studying 1347 Chilean firms. Del Campo et al. [83] studied whether firms located in incubators with more intense innovation strategies better performed, and were measured in terms of their sales revenue, growth, performance, economic and financial profitability than those firms not categorized as innovative and with weaker innovation strategies. They concluded "business incubators generate profitable companies that are sustainable over time, having entrepreneurs with extensive experience in management and high qualifications. This generates quality and lasting employment. However, there is no evidence of significant differences between the more-or-less innovative nature of companies". Cárdenas et al. [84] studied the relation between innovation and agro-industrial SME's development with a nonexperimental design to conclude that innovation was a key factor for their development in the agro-industrial sector. Fernandez et al. [85] studied whether innovation, ICT and the environment influenced revenue growth, using a survey conducted with 250 SMEs. They found that both innovation and ICT positively influenced sales growth and, thus, revenue growth. Another study that surveyed SME concluded that innovation, creativity and technological development allowed SMEs to be more competitive [86]. The relevant study by Cuevas et al. [87] aimed to verify the relation of marketing innovation to SME's overall performance, and its possible implications, through structural equation modeling. The results revealed its significant influence on performance orientation, through new concepts like implementation and promotion means, new marketing methods and packaging modification, which more strongly impacted the commercial, administrative, financial and human resources areas. Mashavira et al. [88] found a positive and significant relationship between managerial interpersonal competencies and firm performance as measured by innovation and return on investment (ROI). CSR is also recognised as an important driver of innovation in companies [89].

Innovation gives companies a competitive advantage and can change the structure of an industry and a country's economy. Specifically, innovation focused on sustainability has led to improvements in the financial performance of the firm as well as in the social and environmental dimensions [90]. Results show that sustainable innovation is positively associated with SME growth [91], measured by the level of employment. Successful implementation of innovation brings about significant growth in the technical and economic 
efficiency of a firm, as reflected in its productivity [92,93], which has important implications for long-term sustainable growth. Results show that the adoption of certain sustainability actions influences consumer perceptions, which in turn impacts on the economic performance of SMEs [94]. Klewitz et al. [10] conducted a systematic review on sustainability innovation in SMEs for the period between 1987 and 2010.

Looking at firm size, both in large firms and SMEs, differences and similarities can be observed in relation to the effects of innovation. On the one hand, regardless of size, investment in $\mathrm{R}$ and $\mathrm{D}$, research resources and product innovation have a positive impact on business performance in terms of revenue and labour productivity. However, in terms of business performance, in large firms it is process innovation that generates the positive effect, while in SMEs it is R and D cooperation. On the other hand, both large firms and SMEs need to focus on technological innovations to improve their sustainability and thus ensure their long-term success [95].

Although there is considerable literature linking innovation to firm performance and growth, however, studies that identify innovative SME with an objective criterion, such as an "innovation seal" awarded and recognized by an official ministry, are lacking. So to the best of our knowledge, no studies are available that, once "Innovative SME" had been identified officially and objectively, compared them with those with environmental sensitivity and assessed whether this fact was beneficial for economic, financial and social profitability.

Specifically, on the relationship between innovation and sustainability, it is indisputable that innovative behaviour is a key element for sustainable competitive advantage, as it allows companies to be flexible and improve their ability to adapt to market changes [96]. In a study for Ghana, results show that sustainable innovation is positively associated with SME growth [91]. The literature reveals a trend towards the notion of a positive relationship between the size of a firm and its innovative activities towards sustainability [90]. The difference, in favor of large companies, is mainly evident in the supply chain and financial model [90]. This argument stems from the greater availability of resources of large firms to innovate their value proposition $[97,98]$, and thus increase the portfolio of products and services they offer to consumers [99]. The lower dynamism of SMEs in implementing sustainable development strategies may also be related to the lack of financial resources to invest in the development of new technologies or environmental and community activities [100]. In terms of $R$ and $D$ activities, the number of, the amount of investment and the number of human resources devoted to $R$ and $D$ and the scale of the company seem to have a positive effect on the patent outcome. In this respect, given the greater difficulty of SMEs compared to large companies in obtaining professional human resources for $\mathrm{R}$ and $\mathrm{D}$, it is believed that governmental policy support for SMEs is necessary to ensure good quality human resources for R and D [101]. A key element is the interaction with external actors (e.g., customers, authorities, research institutes) that can increase the innovative capacity of SMEs on sustainability [10,102].

Focusing on environmental sustainability, we know that environmental degradation is a phenomenon that threatens the survival of mankind and is a key concern of today's society and will be for generations to come, so the environmental performance of SMEs is a highly relevant issue. Researchers need to determine how to assess the environmental performance of SMEs [103]. In reference to the adoption of quality process certifications, the results indicate that, in general, their implementation leads to resource savings from reduced use of electricity, fuel and water for each production unit [104]. However, research suggests that there is a heterogeneous effect of certification on the degree of resource savings, depending on the sector of operation [104]. A paper for SMEs in the UK, relating ISO 14001 implementation and profitability, concludes that, in the long term, there is a positive relationship between environmental performance, i.e., implementation of the standard, and company profitability. However, in the short term, no such relationship is achieved. This is due to the fact that once the standard is implemented, companies do not continue with the implementation of the measures related to it and therefore do not continue to obtain cost 
improvements. However, in the long term, the implementation of the standard has positive effects on the ability to prepare for unforeseen market events [105]. Maas and Reniers [106] note that ISO management systems are used when organizations begin to feel the need to improve their environmental and/or social efficiency. However, these systems can be seen as a way to legitimize environmental performance by organizations without necessarily implying a significant environmental commitment [107]. Environmental certification can be perceived as a marketing tool [108].

The relationship between eco-innovation and environmental sustainability has been extensively investigated in the literature [109]. Sanchez-Medina et al. [110] have investigated 168 Mexican small artisanal firms, and conclude that there is a positive relationship between eco-innovation and the three dimensions of sustainability, economic, social and environmental, adding that "the factors that best explain sustainability are: type of organization, product innovation and process innovation". Empirical research, conducted on a sample of 342 SME manufacturing companies operating in Poland, allows concluding that innovative green initiatives undertaken not only combine environmental objectives with economic ones, but also bring quantifiable benefits to the implementers in parallel to maintaining environmental safety [111]. These green innovations (save energy, prevent pollution or enable waste recycling) do not always translate into higher levels of financial performance. A study of 88 large global companies with a high number of patents shows that greater social approval leads to good environmental initiatives being more likely to acquire a more positive green reputation, to benefit from a higher price and increased sales [112].

From the literature review, it is clear that governmental support policies play a fundamental role in the implementation of measures for sustainability and innovation [113]. Public policies along these lines aim to promote innovation and technological progress to improve competitiveness and economic growth [114,115]. Among the various measures are support for demonstration projects, encouragement of inter-firm partnership, financial support instruments, promotion of international cooperation and human resources training [116,117]. The work of Kim et al. [118] concludes that receiving government certification, as a form of cooperation with the government, has a negative impact on firm performance. In other words, it is necessary to adjust the current government policy of supporting $\mathrm{R}$ and $\mathrm{D}$ of SMEs.

\section{Objective, Materials and Methods}

\subsection{Objective and Hypotheses}

The aim of this article was to analyze whether innovative companies contributed to sustainable growth (and/or sustainability) in its three main pillars: economical, social and environmental. To fulfill this objective, the following hypotheses were put forward:

Hypotheses 1 (H1). The enterprises located in the Valencian Community (east Spain) with an innovation label have more profitability, in other words, results better warranting the statment that they are more likely to remain on the market and are, therefore, more economically sustainable. For this purpose, the economical and financial profitability of enterprises with "Innovative SME" labels were measured and compared with a wide range of companies in the Valencian Community.

Hypotheses 2 (H2). The enterprises located in the Valencian Community (east Spain) with an innovation label have greater social sustainability. Social sustainability was measured in employment-generation terms. The employment generation capacity of enterprises with "Innovative $S M E$ " labels was compared to a wide range of companies in the Valencian Community.

Hypotheses 3 (H3). The enterprises located in the Valencian Community (east Spain) with an innovation label and which are also environmentally sensitive obtain better results, in economical-and financial-profitability terms. In the set of SMEs with an innovation label, economical and financial profitability was compared between those enterprises with some indicator showing environmental sensitivity, such as ISO 14001 or its equivalent, and those without such indicators. 
Hypotheses 4 (H4). The enterprises located in the Valencian Community (east Spain) with an innovation label and which are more environmentally sensitive have greater social sustainability. This hypothesis is based on recognizing the capacity of innovation to create competitive advantage and to achieve higher growth and performance by allowing companies to be more sustainable [1,39-41]. Despite the fact that innovation is present in today's economy, not all enterprises attach the necessary importance to carryout innovative activities. To some extent, and in different ways, most companies innovate, but very few do so consciously, and they do not control the process and perform innovations on an ad hoc basis driven by customer or market demand.

There are several reasons why the Valencian Community was chosen for this study: it is one of the most important regions in Spain, whose economy is fourth in the national ranking, and represents 9.2\% of the Spanish GDP, behind the Autonomous Communities of Madrid, Catalonia and Andalusia. It is also one of the areas with the highest growth and activity. According to the quarterly estimates by the Independent Authority for Fiscal Responsibility (AIREF) [119], in the first quarter of 2020, the Valencian economy grew throughout 2019 at a stable rate of $2.1 \%$, which is similar to that of the national economy. The Survey of Innovative Companies of the National Institute of Statistics 2020 (INE) [120] shows that spending on innovative activities in the Valencian Community accounted for $6.3 \%$ of the total in Spain, which increased by $1.05 \%$ in 2019 compared to 2018. The Valencian Community is a particularly appealing meeting point for a wide range of economic, social and institutional agents linked with science and technology [44].

The first two hypotheses build on previous studies $[81,85,86]$ insofar as they positively affect firms' growth. However, the posed hypotheses focus more on economic and social returns. The third and fourth hypotheses aim to go beyond the findings of Corsi et al. [81] and Del Campo et al. [83] by linking innovation and social responsiveness, insofar as firms take the dual consideration to make more economical and social profitability than those that are only considered innovative. Furthermore, the studies on which the first two hypotheses are based followed different methodologies, as explained in the next section.

To the best of our knowledge, the third and fourth hypotheses are based on the fact that no quantitative studies were found that have compared the economical, financial and social sustainability of an "innovative SME", labeled as innovative to those that are also environmentally sensitive.

In addition, the region has had a Regional Innovation Plan for several years, as stated in the Cotec White Paper (2004) [44]. The Spanish innovation system is defined as "the set of elements that, at the national, regional or local level, act and interact both for and against any process of creation, dissemination or use of economically useful knowledge". The COTEC Foundation considers that the Valencian Community acts as a special appealing meeting point for different economic, social and institutional agents linked with science and technology.

\subsection{Methodology}

Having defined the hypotheses, this section explains the methodology applied to analyze the fulfillment of these hypotheses. A flow chart in Figure 1 presents the methodology approach.

We first identified the companies in the Valencian Community that were considered innovative by using the objective criterion of those with the "Innovative SME" seal, covered by Order ECC/1087/2015, of 5 June, which regulates Innovative SME's seals and creates the Register of Innovative SME. These companies were compared to all the SME in the Valencian Community that performed the same activity as innovative ones. Activities were grouped according to the Spanish classification in Spanish Royal Decree 475/2007.

The companies classified as "Innovative SME" were also classified as those that were environmentally sensitive. The indicator used for this classification was having ISO 14001 or other similar indicators that demonstrate that these companies are concerned about the environment. 


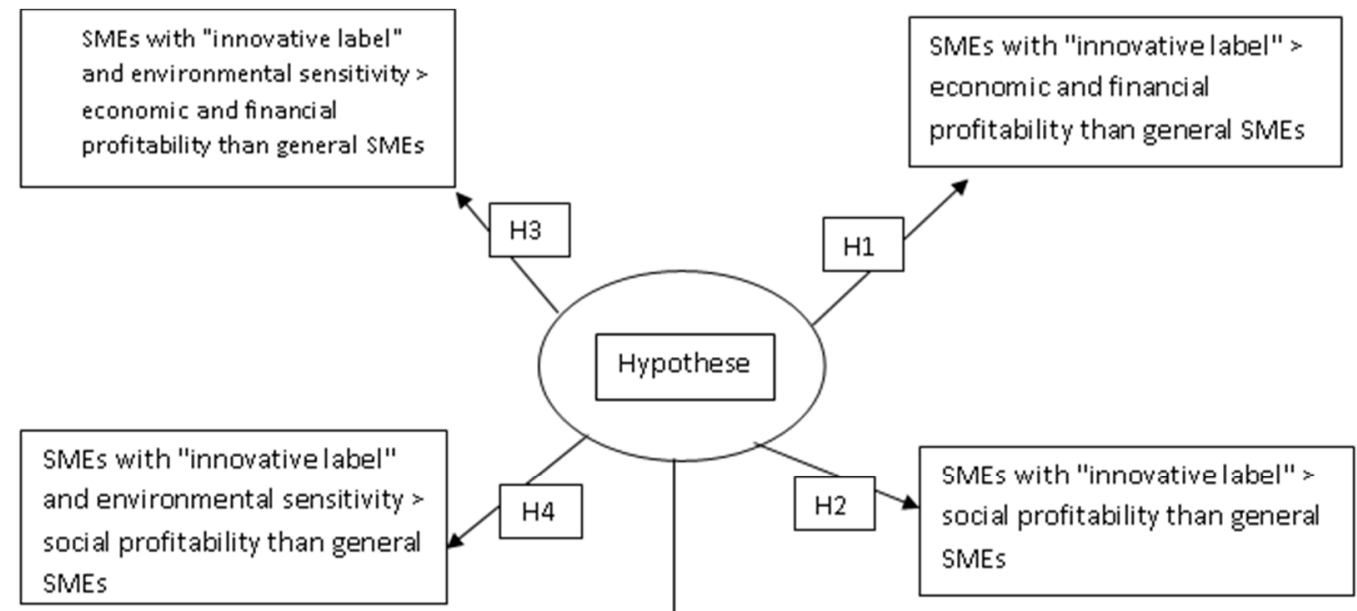

Population: Total SMEs in the Valendan Community (Spain) that have published their annual accounts in the official public register.
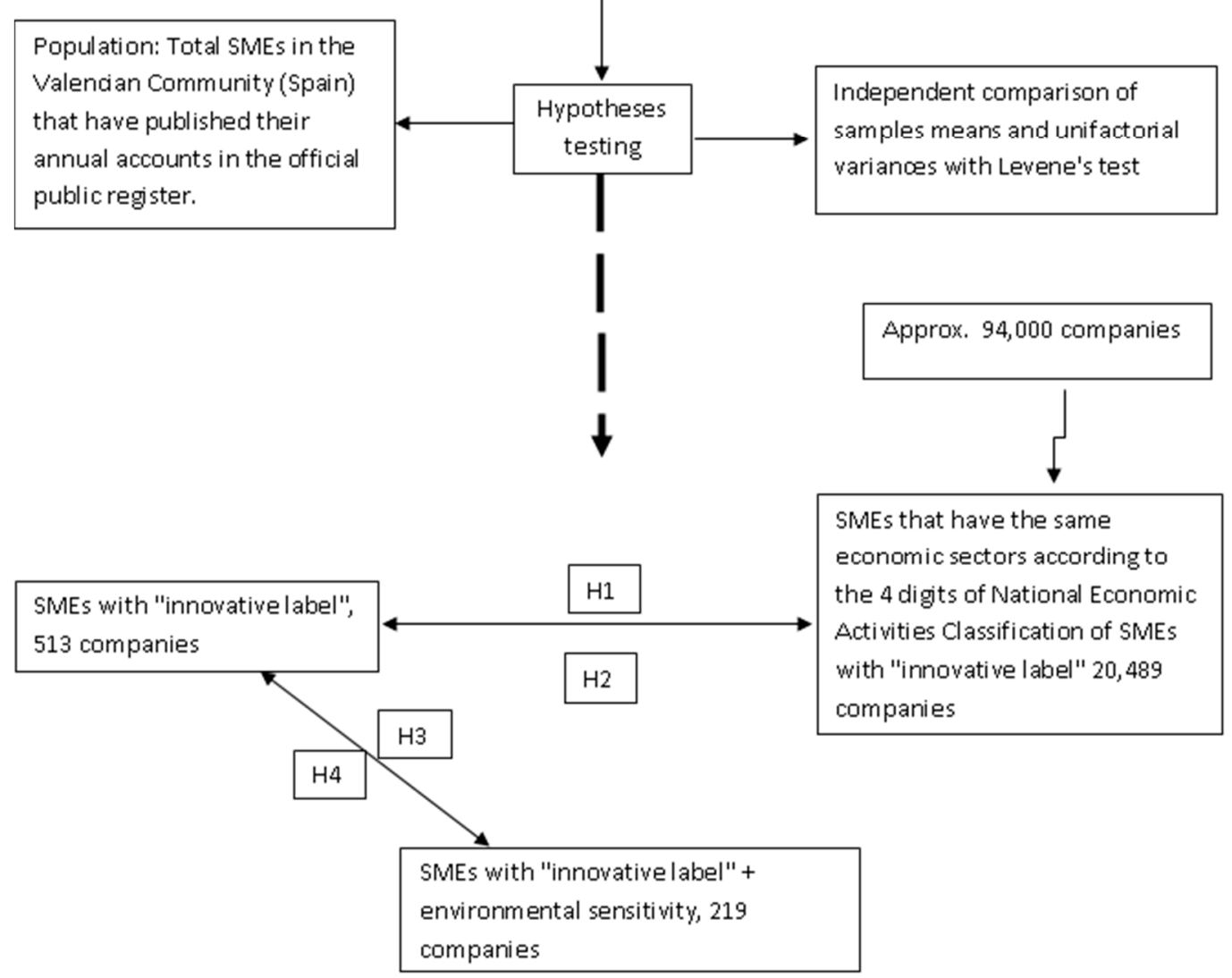

Figure 1. Methodological approach.

In order to measure economic sustainability, the data and ratios related to companies' economic profitability, measured as gross profit before tax divided by total assets, were employed. Financial profitability, measured as the profit after tax to equity ratio, was also used. For social profitability, job creation indicators were applied from a static perspective with employment per company in 2019, which was the last year that annual accounts were published, and from a dynamic perspective, with a change in the total and employment percentages for the 2015-2019 period. Companies, and economic, financial and employment generation data, were grouped according to the four-digit National Classification of 
Economic Activities and aggregated to one digit, with economic and financial information presented in profitability percentage terms.

The hypotheses were tested by the mean Levene's test version to test equal variances, as well as the statistics allowing economical, financial and environmental profitability to be measured. Information was analyzed in absolute numbers corresponding to the economic and financial profitability components to obtain the means. Levene's test was applied to calculate the significance of these absolute numbers.

To the best of our knowledge, this study sheds some light on knowledge about innovation and environmental studies. It compares the SME with the "Innovative Label" to all the SME in a given geographic area to contrast previous hypotheses based on the theoretical framework. The comparison was made to public evidence for the annual accounts presented at the official register and classified according to the National Classification of Economic Activities. The hypotheses were tested by a one-factor analysis of variance (ANOVA) technique with Levene's test. This work took one step further by comparing the companies with "Innovative SME" labels to those that were environmentally sensitive by analyzing whether there were significant differences in economical, financial and social sustainability.

\subsection{Samples and Techniques}

The analysis focused on those enterprises in the Valencian Community which, according to the information taken in December 2020, obtained the distinction that grants the designation of "Innovative SME" [121]. The "Innovative SME" designation is contemplated in Order ECC / 1087/2015, of 5 June, which regulates the subsidy granted to enterprises performing activities in the research, technological development and innovation field. The requirements to be met by the company to obtain the Innovative SME label are as follows.

First, having received public funding in the last 3 years through three channels: public calls as part of the National Plan for Scientific Research, Development and Technological Innovation framework or the State Plan for Scientific and Technical Research and Innovation; having received aid from the Centre for Industrial Technological Development for $\mathrm{R}$ and $\mathrm{D}$ and I projects; through calls from the Framework Programme for R and D and I or the Horizon 2020 programme financed by the European Union.

Second, the firm's innovative character must be demonstrated by possessing own patents in operations or a binding reasoned report.

Third, having acquired one of the official certifications from the Spanish Ministry of Economy according to Aenor Specification EA0043 or EA0047, or according to Standard UNE 166.002, for R and D and I management systems. The enterprises accredited with the label can obtain various tax benefits and can gain access to public funding lines that benefit a company's brand image.

Data about enterprises were acquired from $\mathrm{SABI}{ }^{\circledR}$, a database containing information on the annual accounts of Spanish and Portuguese companies. SABI ${ }^{\circledR}$ collects information from companies that are obliged to file their accounts with the Mercantile Register. These firms are mainly incorporated as Private Limited or Public Limited companies. Table 1 offers the number of enterprises with innovative labels in the Valencian Community, which amount to 584 enterprises, and their location distribution appears in Figure 2. Of these, 39 were extinguished. It was noteworthy that 16 ( $41 \%$ of extinguished labels) disappeared in 2020, a period that coincided with the COVID-19 crisis. Thirty-one companies that appeared as operational did not send their data to commercial registers. This meant that the number of enterprises currently with a seal and provide information about their accounts amounted to 514 companies. To make a homogeneous comparison between innovative SME and a region's companies on the whole, the companies with an innovative label were classified according to the four-digit National Classification of Economic Activities (CNAE-2009). 
Table 1. Companies awarded the innovation label in the Valencian Community.

\begin{tabular}{ccc}
\hline Year & No. & \% s/Total \\
\hline 2015 & 2 & $0.34 \%$ \\
\hline 2016 & 3 & $0.51 \%$ \\
\hline 2017 & 2 & $0.34 \%$ \\
\hline 2018 & 3 & $0.51 \%$ \\
\hline 2019 & 13 & $2.23 \%$ \\
\hline 2020 & 16 & $2.74 \%$ \\
\hline Notally Extinguished & 39 & $6.68 \%$ \\
\hline With label and deposit accounts & 32 & $5.48 \%$ \\
\hline Total & 513 & $87.84 \%$ \\
\hline
\end{tabular}

Source: the authors based their research on Spanish Ministry of Science and Innovation data [121].
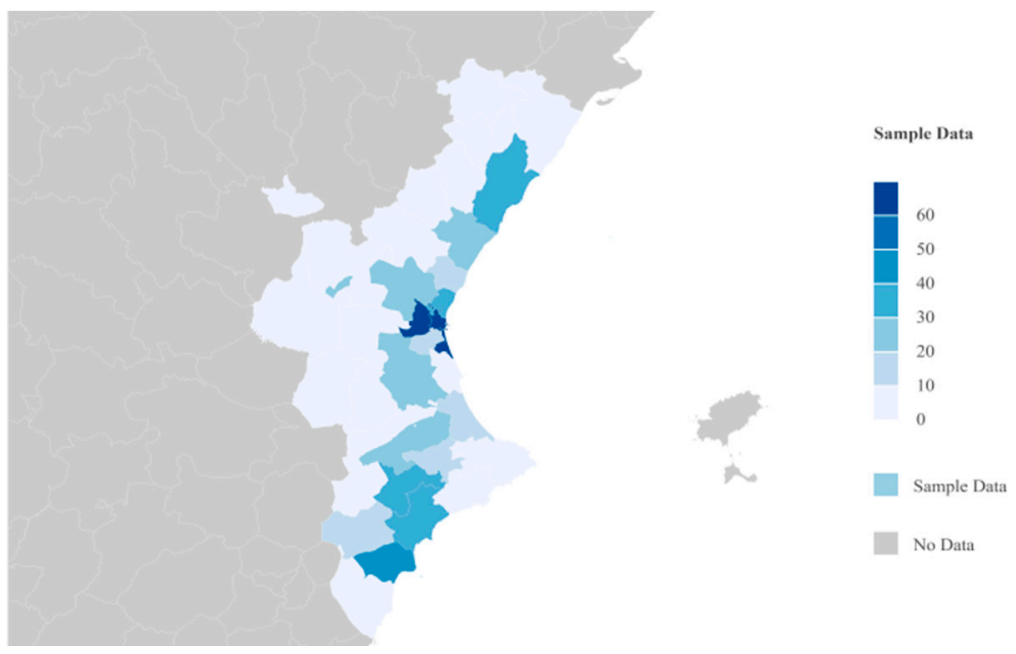

Figure 2. Distribution of the "Innovative SME" label in the Valencian Community.

In order to make a comparison between the companies with an innovative seal and the set of SME in the chosen area, the SABI database was used and a search was initially made for companies by considering all those that provided data according to operating income in either 2018 or 2019. The result of the search gave approximately 94,000 companies. The comparison between companies with an innovative label and all the SME on the whole was made with the CNAE activity code. In other words, the innovative SME belonging to 170 economic activities according to 4-digit CNAE codes were compared to all the SME set included in these classifications. Then the companies selected at the 1-digit level in the classification were aggregated to facilitate the presentation of the results. To not distort the comparison sense, when considering all the SME according to the 4-digit CNAE, all those belonging to the activity codes in which the SME with an innovative label were not present should be eliminated from the search. The total participating companies with the 170 CNAEs of the innovative label amounted to approximately 45,000.

A further step had to be taken, that of refining the search again to compare job creation in the last 4 years. For this purpose, of the total number of SME with the aforementioned characteristics, only those that provided employment data for the last 4 years were selected. That is, those 20,489 SME in the study area that provided income data in 2019 or 2018, as well as their employment level in the last 4 years. 
Therefore, the 513 enterprises with data and innovation labels were compared to the 20,489 companies in the study area included in the 170 economic sectors (primary codes CNAE-2009 to 4 digits) which included innovative SME.

The creation of the "Innovative SME" label aims to highlight SME's activity to promote their identification and to help in the subsequent formulation of their specific policies. After obtaining the "Innovative SME" label, the enterprise is able to:

- Display the awarded logo

- Use the logo in its commercial traffic and for advertising purposes, which is subject to fully complying with the applicable regulations, particularly as regards advertising

- Access tax benefits and rebates from Social Security contributions, as set out in Article 6 of Spanish Royal Decree 475/2014.

\section{Quantitative Analysis}

\subsection{Statistical Analysis of the SME with the "Innovative SME" Label}

Table 2 shows that of the 513 SME with data in 2021,39.49\% had an expired label, of which the label for $11.67 \%$ expired at the peak of the COVID-19 crisis. It can be stated that in 2020, the pandemic paralyzed many matters. The Public Administration was overwhelmed by the situation. It had to process thousands of Temporary Employment Regulation Files and make teleworking decisions when the country was not prepared to take on this situation all at once. All this could have influenced the 2020 label expiry data.

Table 2. Enterprises with the SME Innovation label and expiry date.

\begin{tabular}{ccc}
\hline Expiry Year & No. & $\%$ \\
\hline 2018 & 126 & $24.56 \%$ \\
\hline 2019 & 16 & $3.12 \%$ \\
\hline 2020 & 60 & $11.70 \%$ \\
\hline 2021 & 108 & $21.05 \%$ \\
\hline 2022 & 101 & $19.69 \%$ \\
\hline 2023 & 95 & $18.52 \%$ \\
\hline 2024 & 2 & $0.39 \%$ \\
\hline 2025 & 5 & $0.97 \%$ \\
\hline Total & 513 & $100.00 \%$ \\
\hline SME with a valid seal & 311 & $60.62 \%$ \\
\hline
\end{tabular}

Source: the authors based their research on Spanish Ministry of Science and Innovation data [121].

Table 3 shows information on the number of innovative enterprises per CNAE group. These companies are present in 14 groups of the 21 CNAE groups, which represent $66.6 \%$. The group with the most companies with an innovative label is manufacturing with $49.7 \%$ of the total. In second place comes the professional, scientific and technical group with $15.6 \%$, followed by information and communications with $14.4 \%$. Wholesale and retail trade is the last group to exceed $10 \%$ with $11.7 \%$. Regarding economical and financial profitability, and according to the variables selected to assess economical sustainability, the results indicated that the highest profitability was made by the Professional, scientific and technical group with an average percentage of $26.6 \%$ for economical profitability and $43.2 \%$ for financial profitability, which were well above the levels for the other activity groups. 
Table 3. Economical and financial profitability of "Innovative SME" classified per economic sector.

\begin{tabular}{|c|c|c|c|c|c|}
\hline Group Code & Description & No. & $\%$ & $\begin{array}{l}\text { Economical } \\
\text { Profitability }\end{array}$ & $\begin{array}{c}\text { Financial } \\
\text { Profitability }\end{array}$ \\
\hline A & Agriculture, livestock, forestry and fisheries & 3 & $0.58 \%$ & $-1.48 \%$ & $-6.53 \%$ \\
\hline $\mathrm{B}$ & Extractive industries & 1 & $0.19 \%$ & $29.06 \%$ & $35.19 \%$ \\
\hline $\mathrm{C}$ & Manufacturing industry & 255 & $49.71 \%$ & $7.08 \%$ & $13.68 \%$ \\
\hline $\mathrm{E}$ & Water supply & 5 & $0.97 \%$ & $5.88 \%$ & $18.29 \%$ \\
\hline $\mathrm{F}$ & Construction & 12 & $2.34 \%$ & $3.00 \%$ & $8.03 \%$ \\
\hline G & Wholesale and retail & 60 & $11.70 \%$ & $6.21 \%$ & $13.46 \%$ \\
\hline $\mathrm{H}$ & Transport \& storage & 3 & $0.58 \%$ & $8.11 \%$ & $56.69 \%$ \\
\hline $\mathrm{J}$ & Information and communications & 74 & $14.42 \%$ & $7.78 \%$ & $18.32 \%$ \\
\hline K & Financial and insurance activities & 2 & $0.39 \%$ & $1.15 \%$ & $2.08 \%$ \\
\hline $\mathrm{L}$ & Real-estate activities & 2 & $0.39 \%$ & $4.21 \%$ & $4.36 \%$ \\
\hline M & Professional, scientific and technical activities & 80 & $15.59 \%$ & $26.58 \%$ & $43.22 \%$ \\
\hline $\mathrm{N}$ & Administrative activities and auxiliary services & 5 & $0.97 \%$ & $12.26 \%$ & $30.59 \%$ \\
\hline $\mathrm{P}$ & Education & 1 & $0.19 \%$ & $5.09 \%$ & $10.02 \%$ \\
\hline \multirow[t]{2}{*}{ Q } & Health and social work activities & 10 & $1.95 \%$ & $16.78 \%$ & $28.97 \%$ \\
\hline & Total & 513 & $100 \%$ & $10.2 \%$ & $19.4 \%$ \\
\hline
\end{tabular}

Source: the authors based their research on Spanish Ministry of Science and Innovation data [121] and SABI ${ }^{\circledR}$.

On employment, for each code Table 4 shows the average employment, the average growth and the percentage growth of employment for each activity group. It is noteworthy that in the groups with the most companies with an innovative label, average employment growth is similar in C, G and J, and is lower in the M group. Furthermore, the average percentage change in employment growth is significant at over $74.8 \%$, and reaches $129 \%$ for the group of companies corresponding to group J. In those groups with the most companies with an innovative label, the sector with the most employees per company was Manufacturing (62.1 jobs/company) and in job creation terms, for the 2015-2019 period, the most dynamic sector was Information and Communications.

Table 4. Social sustainability of "Innovative SME" classified per economic group.

\begin{tabular}{|c|c|c|c|c|}
\hline Group Code & Description & $\begin{array}{c}\text { Average } \\
\text { Employment } 2019\end{array}$ & $\begin{array}{c}\text { Average Employment } \\
\text { Growth } \\
\text { 2015-2019 }\end{array}$ & $\begin{array}{c}\text { Average Employment } \\
\text { Growth \% } \\
\text { 2015-2019 }\end{array}$ \\
\hline A & $\begin{array}{l}\text { Agriculture, livestock, forestry and } \\
\text { fisheries }\end{array}$ & 83.7 & 33.3 & $70.0 \%$ \\
\hline $\mathrm{B}$ & Extractive industries & 42.0 & -4.0 & $-8.7 \%$ \\
\hline $\mathrm{C}$ & Manufacturing industry & 62.1 & 13.1 & $51.4 \%$ \\
\hline $\mathrm{E}$ & Water supply & 95.4 & 31.0 & $211.6 \%$ \\
\hline $\mathrm{F}$ & Construction & 33.3 & 7.7 & $39.6 \%$ \\
\hline G & Wholesale and retail & 47.8 & 12.9 & $73.7 \%$ \\
\hline $\mathrm{H}$ & Transport \& storage & 100.7 & 12.0 & $13.4 \%$ \\
\hline $\mathrm{J}$ & Information and communications & 37.2 & 15.8 & $129.0 \%$ \\
\hline K & Financial and insurance activities & 16.0 & 10.0 & $88.9 \%$ \\
\hline $\mathrm{L}$ & Real-estate activities & 4.0 & 0.0 & $42.9 \%$ \\
\hline M & $\begin{array}{l}\text { Professional, scientific and } \\
\text { technical activities }\end{array}$ & 27.0 & 7.6 & $90.0 \%$ \\
\hline
\end{tabular}


Table 4. Cont.

\begin{tabular}{ccccc}
\hline Group Code & Description & $\begin{array}{c}\text { Average } \\
\text { Employment 2019 }\end{array}$ & $\begin{array}{c}\text { Average Employment } \\
\text { Growth } \\
\mathbf{2 0 1 5 - 2 0 1 9}\end{array}$ & $\begin{array}{c}\text { Average Employment } \\
\text { Growth \% } \\
\mathbf{2 0 1 5 - 2 0 1 9}\end{array}$ \\
\hline $\mathrm{N}$ & $\begin{array}{c}\text { Administrative activities and } \\
\text { auxiliary services }\end{array}$ & 33.8 & 14.3 & $297.9 \%$ \\
\hline $\mathrm{P}$ & Education & 103.0 & 32.0 & $45.1 \%$ \\
\hline $\mathrm{Q}$ & Health and social work activities & 28.7 & 9.0 & $42.2 \%$ \\
\hline
\end{tabular}

Source: the authors based their research on Spanish Ministry of Science and Innovation data [121] and SABI ${ }^{\circledR}$.

On the firm's legal denomination, Table 5 shows that the vast majority are Private Limited Companies, which is logical as they are SME. Although Private Limited Companies are smaller in size, they have higher economic and financial profitability, and are also more dynamic in job creation terms.

Table 5. The economic and financial profitability and job creation of "Innovative SME" per legal form.

\begin{tabular}{|c|c|c|c|c|c|c|c|}
\hline $\begin{array}{l}\text { Type of Legal } \\
\text { Form }\end{array}$ & No. & $\%$ Total & $\begin{array}{l}\text { Economical } \\
\text { Profitability }\end{array}$ & $\begin{array}{c}\text { Financial } \\
\text { Profitability }\end{array}$ & $\begin{array}{c}\text { Average } \\
\text { Employment } \\
2019\end{array}$ & $\begin{array}{c}\text { Average } \\
\text { Employment } \\
\text { Growth } \\
\text { 2015-2019 }\end{array}$ & $\begin{array}{c}\text { Average } \\
\text { Employment } \\
\text { Growth \% } \\
2015-2019\end{array}$ \\
\hline $\begin{array}{c}\text { Public Limited } \\
\text { Company }\end{array}$ & 93 & $18.2 \%$ & $6.8 \%$ & $8.6 \%$ & 75.0 & 11.6 & $22.9 \%$ \\
\hline $\begin{array}{c}\text { Private Limited } \\
\text { Companies }\end{array}$ & 420 & $81.8 \%$ & $11.0 \%$ & $21.8 \%$ & 44.5 & 12.9 & $86.6 \%$ \\
\hline Total & 513 & $100 \%$ & $10.2 \%$ & $19.4 \%$ & 50.1 & 12.6 & $74.8 \%$ \\
\hline
\end{tabular}

Source: the authors based their research on Spanish Ministry of Science and Innovation data [121] and SABI ${ }^{\circledR}$.

The Private Limited Companies predominated all the enterprises with an innovative label $(81.8 \%)$, which made higher profitability and generated more average employment per company than Public Limited Companies.

\subsection{Analysis of Companies with an Innovative Label and Environmental Concern}

Having analyzed the innovative SME's characteristics in profitability and job creation terms, i.e., economical and social sustainability, we focused on those that, in addition to innovating, were environmentally sustainable according to Tables 6-8.

Table 6. Economical and financial profitability of environmentally sensitive "Innovative SME" classified per economic sector.

\begin{tabular}{cccccc}
\hline Group Code & Description & No. & $\%$ & $\begin{array}{c}\text { Economical } \\
\text { Profitability }\end{array}$ & $\begin{array}{c}\text { Financial } \\
\text { Profitability }\end{array}$ \\
\hline A & Agriculture, livestock, forestry and fisheries & 2 & $0.90 \%$ & $5.21 \%$ & $10.45 \%$ \\
\hline B & Extractive industries & 1 & $0.50 \%$ & $29.06 \%$ & $35.19 \%$ \\
\hline C & Manufacturing industry & 135 & $61.60 \%$ & $7.79 \%$ & $14.73 \%$ \\
\hline E & Water supply & 4 & $1.80 \%$ & $5.75 \%$ & $18.87 \%$ \\
\hline F & Construction & 6 & $2.70 \%$ & $5.92 \%$ & $11.72 \%$ \\
\hline G & Wholesale and retail & 19 & $8.70 \%$ & $7.27 \%$ & $16.20 \%$ \\
\hline H & Transport \& storage & 3 & $1.40 \%$ & $7.78 \%$ & $36.69 \%$ \\
\hline $\mathrm{J}$ & Information and communications & 14 & $6.40 \%$ & $-1.40 \%$ & $-0.42 \%$ \\
\hline
\end{tabular}


Table 6. Cont.

\begin{tabular}{cccccc}
\hline Group Code & Description & No. & $\%$ & $\begin{array}{c}\text { Economical } \\
\text { Profitability }\end{array}$ & $\begin{array}{c}\text { Financial } \\
\text { Profitability }\end{array}$ \\
\hline $\mathrm{M}$ & Professional, scientific and technical activities & 30 & $13.70 \%$ & $-4.66 \%$ & $15.70 \%$ \\
\hline $\mathrm{N}$ & Administrative activities and auxiliary services & 3 & $1.40 \%$ & $11.50 \%$ & $25.19 \%$ \\
\hline $\mathrm{Q}$ & Health and social work activities & 2 & $0.90 \%$ & $35.70 \%$ & $56.97 \%$ \\
\hline & Total & 219 & $100 \%$ & $5.73 \%$ & $14.90 \%$ \\
\hline
\end{tabular}

Source: the authors based their research on Spanish Ministry of Science and Innovation data [121] and SABI ${ }^{\circledR}$.

Table 7. Job creation of environmentally sensitive "Innovative SMEs", classified per economic sector.

\begin{tabular}{|c|c|c|c|c|}
\hline Group Code & Description & $\begin{array}{c}\text { Average } \\
\text { Employment } 2019\end{array}$ & $\begin{array}{c}\text { Average Employment } \\
\text { Growth } \\
\text { 2015-2019 }\end{array}$ & $\begin{array}{c}\text { Average Employment } \\
\text { Growth \% } \\
2015-2019\end{array}$ \\
\hline A & $\begin{array}{c}\text { Agriculture, livestock, forestry and } \\
\text { fisheries }\end{array}$ & 21.50 & 7.50 & $70.50 \%$ \\
\hline B & Extractive industries & 42.00 & -4.00 & $-8.70 \%$ \\
\hline $\mathrm{C}$ & Manufacturing industry & 73.49 & 15.19 & $47.30 \%$ \\
\hline $\mathrm{E}$ & Water supply & 106.50 & 27.25 & $34.50 \%$ \\
\hline $\mathrm{F}$ & Construction & 55.00 & 11.17 & $28.80 \%$ \\
\hline G & Wholesale and retail & 67.79 & 25.42 & $117.30 \%$ \\
\hline $\mathrm{H}$ & Transport \& storage & 100.67 & 12.00 & $13.40 \%$ \\
\hline $\mathrm{J}$ & Information and communications & 91.00 & 40.71 & $203.00 \%$ \\
\hline M & $\begin{array}{l}\text { Professional, scientific and } \\
\text { technical activities }\end{array}$ & 41.13 & 8.90 & $55.40 \%$ \\
\hline $\mathrm{N}$ & $\begin{array}{c}\text { Administrative activities and } \\
\text { auxiliary services }\end{array}$ & 46.00 & 13.33 & $25.90 \%$ \\
\hline \multirow[t]{2}{*}{ Q } & Health and social work activities & 73.00 & 40.00 & $113.20 \%$ \\
\hline & Total & 49.66 & 12.33 & $73.10 \%$ \\
\hline
\end{tabular}

Source: the authors based their research on Spanish Ministry of Science and Innovation data [121] and SABI ${ }^{\circledR}$.

Table 8. Economical, financial and social profitability of the environmentally sensitive "Innovative SME" classified per legal form.

\begin{tabular}{|c|c|c|c|c|c|c|c|}
\hline Type & No. & $\begin{array}{l}\% \text { of the } \\
\text { Total }\end{array}$ & $\begin{array}{l}\text { Economical } \\
\text { Profitability }\end{array}$ & $\begin{array}{c}\text { Financial } \\
\text { Profitability }\end{array}$ & $\begin{array}{c}\text { Average } \\
\text { Employment } \\
2019\end{array}$ & $\begin{array}{c}\text { Average } \\
\text { Employment } \\
\text { Growth } \\
\text { 2015-2019 }\end{array}$ & $\begin{array}{c}\text { Average } \\
\text { Employment } \\
\text { Growth \% } \\
\text { 2015-2019 }\end{array}$ \\
\hline $\begin{array}{l}\text { Public Limited } \\
\text { Company }\end{array}$ & 54 & $24.66 \%$ & $4.67 \%$ & $10.48 \%$ & 79.70 & 13.04 & $23.51 \%$ \\
\hline $\begin{array}{l}\text { Private Limited } \\
\text { Companies }\end{array}$ & 165 & $75.34 \%$ & $6.08 \%$ & $16.36 \%$ & 65.65 & 18.32 & $78.49 \%$ \\
\hline Total & 219 & $100 \%$ & $5.7 \%$ & $14.9 \%$ & 69.13 & 17.00 & $64.37 \%$ \\
\hline
\end{tabular}

Source: the authors based their research on Spanish Ministry of Science and Innovation data [121] and SABI ${ }^{\circledR}$.

Of all the SMEs with an innovative label and provided data, 219 were identified as being environmentally sensitive, which represents $45.7 \%$ of innovative SME, compared to $54.3 \%$, and 260 companies with no identified environmental certification or environmental actions. 
By taking another step further, and of the SME with an "Innovative SME" label, we focused on the environmentally sensitive ones. We observed that they concentrated in the manufacturing industry activity group $(61.6 \%)$, and the professional activities group came second $(13.7 \%$ ) (see Table 6$)$. In economical sustainability terms, the activity groups with the highest economical profitability were the manufacturing industry $(7.79 \%)$ and wholesale and retail trade $(7.27 \%)$, in those groups with the most companies with an environmentally sensitive. In social sustainability and job creation terms, the information and communications activities group once again stood out with $203 \%$ employment growth for the 2015-2019 period and was the group with the highest employment growth per company with 91 professionals (see Table 7).

In addition, for the group of companies with a label that were also environmentally sensitive, the Public Limited Companies (24.7\%) had an average increase in jobs of $23.5 \%$ with an average of 79.7 new jobs per company. The Private Limited Companies created more jobs overall, although the average number of jobs created per company is lower (see Table 8).

\subsection{General Enterprises Analysis}

The employment evolution, and the economical and financial profitability of the SMEs officially located in the Valencian Community that had submitted their data to the Mercantile Register in 2020 and employment data for 2019-2015 were analyzed. In Article 365 of the Mercantile Register Regulations (RD 1784/96 of 19 July), Spanish legislation establishes "The administrators of Public Limited Companies, Private Limited Companies and any other entrepreneurs who, by virtue of the provisions in force, are obliged to publish their annual accounts, shall submit them for filing at the Mercantile Register of their official address within 1 month following their approval". Figure 3 depicts the geographical distribution of SME in the Valencian Community, and Figure 4 indicates their distribution according to their turnover. Of these enterprises, those belonging to the 4-digit CNAE codes in which innovative SME are present were selected. This consideration was taken to compare the results and job creation of innovative SME to those of all the SME in the study area.

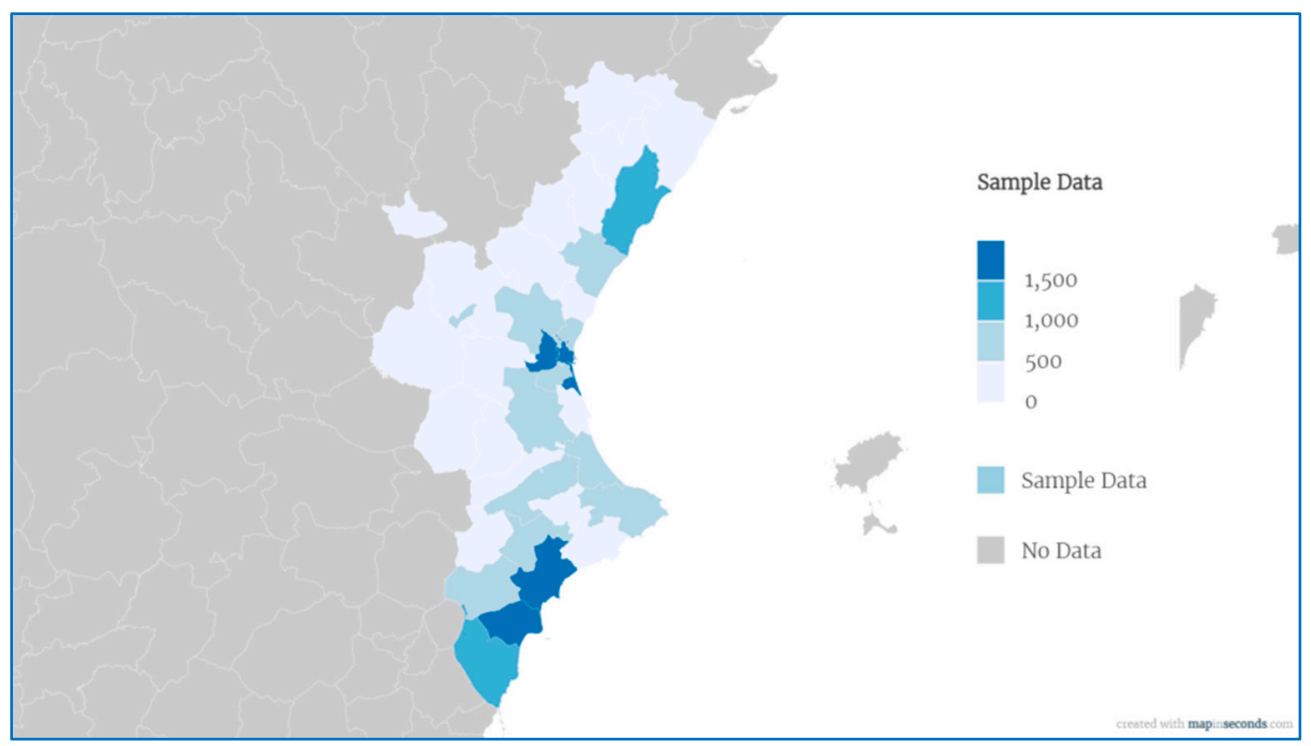

Figure 3. County SME distribution. 


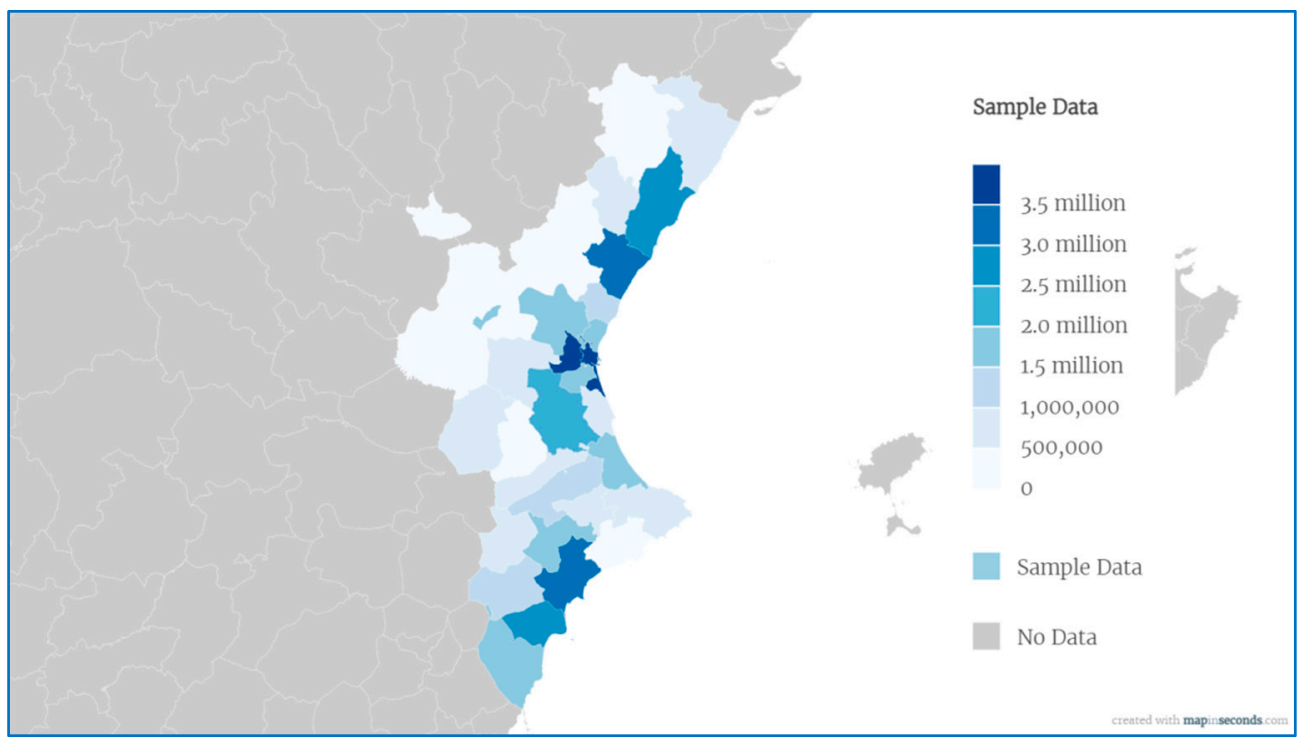

Figure 4. County SME distribution for turnover.

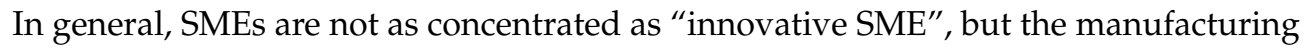
sector stands out, together with wholesale and retail trade, for accounting for $25.5 \%$ and $25.9 \%$ of companies, respectively, followed by the construction group with $16.2 \%$. The information and communications group had the highest economical (13.4\%) and financial $(25.1 \%)$ profitability among the most represented groups, as Table 9 shows. They were also those that created the most jobs per company and for the 2015-2019 period as Table 10 shows.

Table 9. The economical and financial profitability of the SME classified per economic sector.

\begin{tabular}{|c|c|c|c|c|c|}
\hline Group Code & Description & No. & $\%$ & $\begin{array}{l}\text { Economical } \\
\text { Profitability }\end{array}$ & $\begin{array}{c}\text { Financial } \\
\text { Profitability }\end{array}$ \\
\hline $\mathrm{A}$ & $\begin{array}{l}\text { Agriculture, livestock, forestry } \\
\text { and fisheries }\end{array}$ & 113 & $0.60 \%$ & $6.82 \%$ & $18.04 \%$ \\
\hline B & Extractive industries & 2 & $0.00 \%$ & $27.60 \%$ & $33.95 \%$ \\
\hline $\mathrm{C}$ & Manufacturing industry & 5222 & $25.50 \%$ & $5.93 \%$ & $11.49 \%$ \\
\hline $\mathrm{E}$ & Water supply & 112 & $0.50 \%$ & $11.21 \%$ & $23.07 \%$ \\
\hline $\mathrm{F}$ & Construction & 3312 & $16.20 \%$ & $3.93 \%$ & $8.89 \%$ \\
\hline G & Wholesale and retail & 5307 & $25.90 \%$ & $5.66 \%$ & $11.32 \%$ \\
\hline $\mathrm{H}$ & Transport \& storage & 1265 & $6.20 \%$ & $6.17 \%$ & $11.67 \%$ \\
\hline $\mathrm{J}$ & Information and communications & 628 & $3.10 \%$ & $13.41 \%$ & $25.08 \%$ \\
\hline K & Financial and insurance activities & 228 & $1.10 \%$ & $5.43 \%$ & $6.55 \%$ \\
\hline $\mathrm{L}$ & Real-estate activities & 1559 & $7.60 \%$ & $3.43 \%$ & $4.61 \%$ \\
\hline M & $\begin{array}{c}\text { Professional, scientific and } \\
\text { technical activities }\end{array}$ & 1634 & $8.00 \%$ & $9.82 \%$ & $15.36 \%$ \\
\hline $\mathrm{N}$ & $\begin{array}{c}\text { Administrative activities and } \\
\text { auxiliary services }\end{array}$ & 502 & $2.50 \%$ & $5.04 \%$ & $7.88 \%$ \\
\hline $\mathrm{P}$ & Education & 197 & $1.00 \%$ & $3.43 \%$ & $6.40 \%$ \\
\hline \multirow[t]{2}{*}{ Q } & Health and social work activities & 408 & $2.00 \%$ & $9.13 \%$ & $12.65 \%$ \\
\hline & Total & 20,489 & $100 \%$ & $5.95 \%$ & $11.17 \%$ \\
\hline
\end{tabular}


Table 10. Social profitability of the SME classified per economic sector.

\begin{tabular}{|c|c|c|c|c|c|c|c|}
\hline $\begin{array}{l}\text { Group } \\
\text { Code }\end{array}$ & Description & $\begin{array}{c}\text { Total } \\
\text { Employment } \\
2019\end{array}$ & $\begin{array}{c}\text { Total } \\
\text { Employment } \\
2015\end{array}$ & $\begin{array}{c}\text { Average } \\
\text { Employment } \\
\text { per Enterprise } \\
2019\end{array}$ & $\begin{array}{c}\text { Average } \\
\text { Employment } \\
\text { Growth } \\
\text { 2015-2019 }\end{array}$ & $\begin{array}{c}\text { Average } \\
\text { Employment } \\
\text { Growth per } \\
\text { Enterprise } \\
\text { 2015-2019 }\end{array}$ & $\begin{array}{c}\text { Average } \\
\text { Employment } \\
\text { Growth \% } \\
2015-2019\end{array}$ \\
\hline A & $\begin{array}{c}\text { Agriculture, } \\
\text { livestock, forestry } \\
\text { and fisheries }\end{array}$ & 1563 & 1328 & 13.83 & 235 & 2.08 & $17.70 \%$ \\
\hline B & Extractive industries & 46 & 49 & 23.00 & -3 & -1.50 & $-6.12 \%$ \\
\hline C & $\begin{array}{l}\text { Manufacturing } \\
\text { industry }\end{array}$ & 93,019 & 79,473 & 17.81 & 13,546 & 2.59 & $17.04 \%$ \\
\hline $\mathrm{E}$ & Water supply & 2269 & 1890 & 20.26 & 379 & 3.38 & $20.05 \%$ \\
\hline $\mathrm{F}$ & Construction & 29,117 & 21,066 & 8.79 & 8051 & 2.43 & $38.22 \%$ \\
\hline G & Wholesale and retail & 54,382 & 46,309 & 10.25 & 8073 & 1.52 & $17.43 \%$ \\
\hline $\mathrm{H}$ & Transport \& storage & 18,134 & 14,042 & 14.34 & 4092 & 3.23 & $29.14 \%$ \\
\hline $\mathrm{J}$ & $\begin{array}{l}\text { Information and } \\
\text { communications }\end{array}$ & 6809 & 4724 & 10.84 & 2085 & 3.32 & $44.14 \%$ \\
\hline K & $\begin{array}{c}\text { Financial and } \\
\text { insurance activities }\end{array}$ & 1205 & 1484 & 5.29 & -279 & -1.22 & $-18.80 \%$ \\
\hline $\mathrm{L}$ & Real-estate activities & 3932 & 5185 & 2.52 & -1253 & -0.80 & $-24.17 \%$ \\
\hline M & $\begin{array}{c}\text { Professional, } \\
\text { scientific and } \\
\text { technical activities }\end{array}$ & 14,062 & 11,023 & 8.61 & 3039 & 1.86 & $27.57 \%$ \\
\hline $\mathrm{N}$ & $\begin{array}{l}\text { Administrative } \\
\text { activities and } \\
\text { auxiliary services }\end{array}$ & 4904 & 3907 & 9.77 & 997 & 1.99 & $25.52 \%$ \\
\hline $\mathrm{P}$ & Education & 1928 & 1854 & 9.79 & 74 & 0.38 & $3.99 \%$ \\
\hline \multirow[t]{2}{*}{ Q } & $\begin{array}{l}\text { Health and social } \\
\text { work activities }\end{array}$ & 3492 & 3039 & 8.56 & 453 & 1.11 & $14.91 \%$ \\
\hline & Total & 234,862 & 195,373 & 11.46 & 39,489 & 1.93 & $20.21 \%$ \\
\hline
\end{tabular}

Source: the authors based their research on the Ministry of Science and Innovation data [121] and SABI ${ }^{\circledR}$.

\subsection{Comparative Analyses and Fulfilling the Hypotheses}

In order to analyze if the first hypothesis was fulfilled, Table 11 shows a comparative analysis made of the companies with the "Innovation SME" designation and the SME in the Valencian Community, on the whole. When we looked at the sectors under study and those in which innovative SME were present, by starting with a 4-digit level classification and aggregating them to a 1-digit level or group, the companies with an "Innovative SME" label displayed a higher degree of concentration per sector. The manufacturing sector accounts for a higher proportion of innovative companies than SME in general. Forty-nine percent of the innovative companies belong to the manufacturing industry, compared to $25.5 \%$ of SME in general, which gives us an idea of the importance of innovation in this sector. In innovative and environmentally sensitive SME, the weight of manufacturing firms group increase to $61.6 \%$. In the information and communications and professional and scientific activities sectors, the proportion of innovation-labeled firms is higher than the average number of labeled firms compared to the SME on the whole. We confirm that the average economical and financial profitability of innovative SME was higher than that of SME in general. 
Table 11. Comparative analysis of the economical and financial performance of "Innovative SME" and general SME.

\begin{tabular}{|c|c|c|c|c|c|c|c|c|c|}
\hline \multirow{2}{*}{\multicolumn{2}{|c|}{ Group Code Description }} & \multicolumn{5}{|c|}{ Innovative Label } & \multicolumn{3}{|c|}{ Total } \\
\hline & & No. & $\%$ & \multirow{2}{*}{$\begin{array}{c}\begin{array}{c}\text { Economical } \\
\text { Profitability }\end{array} \\
7.08 \%\end{array}$} & \multirow{2}{*}{$\begin{array}{c}\begin{array}{c}\text { Financial } \\
\text { Profitability }\end{array} \\
13.68 \%\end{array}$} & \multirow{2}{*}{$\begin{array}{l}\text { No. } \\
5222\end{array}$} & \multirow{2}{*}{$\begin{array}{c}\% \\
25.50 \%\end{array}$} & \multirow{2}{*}{$\begin{array}{c}\begin{array}{c}\text { Economical } \\
\text { Profitability }\end{array} \\
5.93 \%\end{array}$} & \multirow{2}{*}{$\begin{array}{c}\begin{array}{c}\text { Financial } \\
\text { Profitability }\end{array} \\
11.49 \% \\
\end{array}$} \\
\hline $\mathrm{C}$ & $\begin{array}{l}\text { Manufacturing } \\
\text { industry }\end{array}$ & 255 & $49.71 \%$ & & & & & & \\
\hline G & $\begin{array}{l}\text { Wholesale and } \\
\text { retail }\end{array}$ & 60 & $11.70 \%$ & $6.21 \%$ & $13.46 \%$ & 5307 & $25.90 \%$ & $5.66 \%$ & $11.32 \%$ \\
\hline $\mathrm{J}$ & $\begin{array}{l}\text { Information and } \\
\text { communications }\end{array}$ & 74 & $14.42 \%$ & $7.78 \%$ & $18.32 \%$ & 628 & $3.10 \%$ & $13.41 \%$ & $25.08 \%$ \\
\hline \multirow[t]{3}{*}{$\mathrm{M}$} & $\begin{array}{c}\text { Professional, } \\
\text { scientific and } \\
\text { technical activities }\end{array}$ & 80 & $15.59 \%$ & $26.58 \%$ & $43.22 \%$ & 1634 & $8.00 \%$ & $9.82 \%$ & $15.36 \%$ \\
\hline & Others 10 & 44 & $8.58 \%$ & & & 7698 & $37.60 \%$ & & \\
\hline & Total & 513 & $100 \%$ & $10.20 \%$ & $19.40 \%$ & 20489 & $100 \%$ & $5.95 \%$ & $11.17 \%$ \\
\hline
\end{tabular}

Source: the authors based their research on Spanish Ministry of Science and Innovation data [121] and SABI ${ }^{\circledR}$.

Table 12 shows the innovative companies' independent sample statistics. Data are significant sig $<0.000^{* * *}$ for operating income, profit before tax, assets and shareholders' equity. Therefore, we conclude that the first hypothesis is fulfilled: the enterprises in the Valencian Community (east Spain) that obtain the "Innovative SME" designation make higher economical and financial profitability.

Table 12. Statistics and the independent samples test of the economical and financial profitability of "Innovative SME" and general SME.

\begin{tabular}{|c|c|c|c|c|c|c|c|}
\hline Variables & $\begin{array}{c}\text { Innovative } \\
\text { SME }\end{array}$ & $\mathbf{N}$ & $\begin{array}{l}\text { Average } \\
(\mathrm{m} €)\end{array}$ & $\mathbf{F}$ & Sig. & Levene's Test & $\begin{array}{c}\text { Sig. } \\
\text { (Bilateral) }\end{array}$ \\
\hline \multirow{2}{*}{$\begin{array}{l}\text { Operations Income } \\
2019\end{array}$} & Yes & 453 & $10,097.34$ & \multirow{2}{*}{95.09} & \multirow{2}{*}{0.000} & \multirow{2}{*}{$\begin{array}{c}\text { No variances are } \\
\text { assumed }\end{array}$} & \multirow{2}{*}{0.000} \\
\hline & No & 20,212 & 2761.45 & & & & \\
\hline \multirow{2}{*}{$\begin{array}{c}\text { Profits } \\
\text { (EBT) } \\
2019 \\
\end{array}$} & Yes & 351 & 178.43 & \multirow{2}{*}{505.11} & \multirow{2}{*}{0.000} & \multirow{2}{*}{$\begin{array}{c}\text { No variances are } \\
\text { assumed }\end{array}$} & \multirow{2}{*}{0.000} \\
\hline & No & 19,510 & 53.31 & & & & \\
\hline \multirow{2}{*}{ Assets } & Yes & 79 & 509.43 & \multirow{2}{*}{0.759} & \multirow{2}{*}{0.384} & \multirow{2}{*}{$\begin{array}{l}\text { Variances are } \\
\text { assumed }\end{array}$} & \multirow{2}{*}{0.000} \\
\hline & No & 13,216 & 334.34 & & & & \\
\hline \multirow[t]{2}{*}{ Equity } & Yes & 132 & 411.23 & 17,100 & 0.000 & $\begin{array}{c}\text { No variances are } \\
\text { assumed }\end{array}$ & 0.000 \\
\hline & No & 15,816 & 206.07 & & & & \\
\hline
\end{tabular}

Source: the authors based their research on Spanish Ministry of Science and Innovation data [121] and SABI ${ }^{\circledR}$.

About the second hypothesis on social sustainability, based on the capacity to create jobs, Table 13 shows that the number of employees per company and job creation for the 2015-2019 period are clearly higher for innovative SME than for SME in general. Therefore, the second hypothesis is fulfilled.

The statistics verified that the companies with the "Innovative SME" label were bigger, as measured by the number of workers, and they created more employment during the 2015-2019 period: sigma $<0.000 * * *$ (see Table 14). Therefore, it can be stated that the second hypothesis is fulfilled: the companies located in the Valencian Community (east Spain) with the Innovative SME label generate more employment and obtain greater social sustainability. 
Table 13. Comparative analysis of the social returns of "Innovative SME" and general SME.

\begin{tabular}{|c|c|c|c|c|c|c|c|}
\hline \multirow[b]{2}{*}{$\begin{array}{l}\text { Group } \\
\text { Code }\end{array}$} & \multirow[b]{2}{*}{ Description } & \multicolumn{3}{|c|}{ Innovative Label } & \multicolumn{3}{|c|}{ Total } \\
\hline & & $\begin{array}{c}\text { Average } \\
\text { employment } \\
\text { per Enterprise } \\
2019\end{array}$ & $\begin{array}{c}\text { Average } \\
\text { Employment } \\
\text { Growth per } \\
\text { Enterprise } \\
\text { 2015-2019 }\end{array}$ & $\begin{array}{c}\text { Average } \\
\text { Employment } \\
\text { Growth \% } \\
\text { 2015-2019 }\end{array}$ & $\begin{array}{c}\text { Average } \\
\text { Employment } \\
\text { per Enterprise } \\
2019\end{array}$ & $\begin{array}{c}\text { Average } \\
\text { Employment } \\
\text { Growth per } \\
\text { Enterprise } \\
\text { 2015-2019 }\end{array}$ & $\begin{array}{c}\text { Avergae } \\
\text { Employment } \\
\text { Growth \% } \\
\text { 2015-2019 }\end{array}$ \\
\hline $\mathrm{C}$ & $\begin{array}{l}\text { Manufacturing } \\
\text { industry }\end{array}$ & 62.1 & 13.1 & $51.40 \%$ & 17.81 & 2.59 & $17.04 \%$ \\
\hline G & Wholesale and retail & 47.8 & 12.9 & $73.70 \%$ & 10.25 & 1.52 & $17.43 \%$ \\
\hline $\mathrm{J}$ & $\begin{array}{l}\text { Information and } \\
\text { communications }\end{array}$ & 37.2 & 15.8 & $129.00 \%$ & 10.84 & 3.32 & $44.14 \%$ \\
\hline \multirow[t]{2}{*}{ M } & $\begin{array}{l}\text { Professional, scientific } \\
\text { and technical activities }\end{array}$ & 27.0 & 7.6 & $90.00 \%$ & 8.61 & 1.86 & $27.57 \%$ \\
\hline & Total & 50.1 & 12.6 & $74.80 \%$ & 11.88 & 1.93 & $20.21 \%$ \\
\hline
\end{tabular}

Source: the authors based their research on Spanish Ministry of Science and Innovation data [121] and SABI ${ }^{\circledR}$.

Table 14. Statistics and the independent-samples test of the social profitability of the SMEs with an "Innovative Label" and SME in general.

\begin{tabular}{|c|c|c|c|c|c|c|c|}
\hline Variables & $\begin{array}{c}\text { Innovative } \\
\text { Label }\end{array}$ & No. & Average & $\mathbf{F}$ & Sig. & Levene's Test & $\begin{array}{c}\text { Sig. } \\
\text { (Bilateral) }\end{array}$ \\
\hline \multirow{2}{*}{$\begin{array}{c}\text { Employment } \\
2019\end{array}$} & Yes & 455 & 12.64 & \multirow{2}{*}{161.38} & \multirow{2}{*}{0.000} & \multirow{2}{*}{$\begin{array}{l}\text { No variances are } \\
\text { assumed }\end{array}$} & \multirow{2}{*}{0.000} \\
\hline & No & 20,301 & 11.85 & & & & \\
\hline \multirow{2}{*}{ Employment growth } & Yes & 444 & 12.58 & \multirow{2}{*}{80.29} & \multirow{2}{*}{0.000} & \multirow{2}{*}{$\begin{array}{c}\text { No variances are } \\
\text { assumed }\end{array}$} & \multirow{2}{*}{0.000} \\
\hline & No & 20,301 & 2.56 & & & & \\
\hline
\end{tabular}

Source: the authors based their research on Spanish Ministry of Science and Innovation data [121] and SABI ${ }^{\circledR}$.

In order to show results demonstrating that the third hypothesis was fulfilled, Table 15 was created. It reveals that, of the innovative companies, those belonging to the manufacturing sector account for $49.1 \%$, and those that are environmentally sensitive and are manufacturing companies account for $61.6 \%$. In the commercial sector for the information and communications, and professional, scientific and technical, the relative weight of environmentally sensitive companies decreases. Economical and financial profitability is higher in the SMEs with an "Innovative SME" label than in the group of innovative SMEs that are also environmentally sensitive. Thus, the third hypothesis is not fulfilled when it was states that the enterprises located in the Valencian Community (east Spain) with an "Innovative SME" label are environmentally sensitive and obtain higher economical and financial profitability. Therefore, innovation in environmental aspects is not a driver of increased profitability.

Table 15. Comparative analysis of the economical and financial performance of "Innovative SME" and those that are environmentally sensitive.

\begin{tabular}{|c|c|c|c|c|c|c|c|c|c|}
\hline \multirow{2}{*}{$\begin{array}{l}\text { Group } \\
\text { Code }\end{array}$} & \multirow[b]{2}{*}{ Description } & \multicolumn{4}{|c|}{ Innovative Label } & \multicolumn{4}{|c|}{ Environmentally Sensitive } \\
\hline & & No. & $\%$ & $\begin{array}{l}\text { Economical } \\
\text { Profitability }\end{array}$ & $\begin{array}{c}\text { Financial } \\
\text { Profitability }\end{array}$ & No. & $\%$ & $\begin{array}{l}\text { Economical } \\
\text { Profitability }\end{array}$ & $\begin{array}{c}\text { Financial } \\
\text { Profitability }\end{array}$ \\
\hline $\mathrm{C}$ & $\begin{array}{l}\text { Manufacturing } \\
\text { industry }\end{array}$ & 255 & $49.71 \%$ & $7.08 \%$ & $13.68 \%$ & 135 & $61.60 \%$ & $7.79 \%$ & $14.73 \%$ \\
\hline G & $\begin{array}{l}\text { Wholesale and } \\
\text { retail }\end{array}$ & 60 & $11.70 \%$ & $6.21 \%$ & $13.46 \%$ & 19 & $8.70 \%$ & $7.27 \%$ & $16.20 \%$ \\
\hline $\mathrm{J}$ & $\begin{array}{l}\text { Information and } \\
\text { communications }\end{array}$ & 74 & $14.42 \%$ & $7.78 \%$ & $18.32 \%$ & 14 & $6.40 \%$ & $-1.40 \%$ & $-0.42 \%$ \\
\hline
\end{tabular}


Table 15. Cont.

\begin{tabular}{|c|c|c|c|c|c|c|c|c|c|}
\hline \multirow{2}{*}{$\begin{array}{l}\text { Group } \\
\text { Code }\end{array}$} & \multirow[b]{2}{*}{ Description } & \multicolumn{4}{|c|}{ Innovative Label } & \multicolumn{4}{|c|}{ Environmentally Sensitive } \\
\hline & & No. & $\%$ & $\begin{array}{l}\text { Economical } \\
\text { Profitability }\end{array}$ & $\begin{array}{c}\text { Financial } \\
\text { Profitability }\end{array}$ & No. & $\%$ & $\begin{array}{l}\text { Economical } \\
\text { Profitability }\end{array}$ & $\begin{array}{c}\text { Financial } \\
\text { Profitability }\end{array}$ \\
\hline M & $\begin{array}{c}\text { Professional, } \\
\text { scientific and } \\
\text { technical activities }\end{array}$ & 80 & $15.59 \%$ & $26.58 \%$ & $43.22 \%$ & 30 & $13.70 \%$ & $-4.66 \%$ & $15.70 \%$ \\
\hline & 10 others & 44 & $8.58 \%$ & & & 21 & $9.60 \%$ & & \\
\hline & Total & 513 & $100.00 \%$ & $10.20 \%$ & $19.40 \%$ & 219 & $100.00 \%$ & $5.73 \%$ & $14.90 \%$ \\
\hline
\end{tabular}

Source: the authors based their research on Spanish Ministry of Science and Innovation data [121] and SABI ${ }^{\circledR}$.

Employment growth per enterprise and job creation for the 2015-2019 period were similar for all the innovative and environmentally sensitive SMEs (see Table 16). In job creation terms, no difference was found between the SME with an innovation label and those also with environmental indicators; i.e., they were sensitive to the issue. Therefore, the fourth hypothesis is not fulfilled when it states that the enterprises located in the Valencian Community (east Spain) which, apart from having an innovation label and being more environmentally sensitive, have greater social sustainability.

Table 16. Comparative analysis of the social performance of "Innovative SME" and environmentally sensitive SME.

\begin{tabular}{|c|c|c|c|c|c|c|c|}
\hline \multirow[b]{2}{*}{$\begin{array}{l}\text { Group } \\
\text { Code }\end{array}$} & \multirow[b]{2}{*}{ Description } & \multicolumn{3}{|c|}{ Innovative Label } & \multicolumn{3}{|c|}{ Environmentally Sensitive } \\
\hline & & $\begin{array}{c}\text { Average } \\
\text { Employment } \\
\text { per Enterprise } \\
2019\end{array}$ & $\begin{array}{c}\text { Average } \\
\text { Employment } \\
\text { Growth per } \\
\text { Enterprise } \\
\text { 2015-2019 }\end{array}$ & $\begin{array}{c}\text { Employment } \\
\text { Growth \% } \\
\text { 2015-2019 }\end{array}$ & $\begin{array}{c}\text { Average } \\
\text { Employment } \\
\text { per Enterprise } \\
2019\end{array}$ & $\begin{array}{c}\text { Average } \\
\text { Employment } \\
\text { Growth per } \\
\text { Enterprise } \\
\text { 2015-2019 }\end{array}$ & $\begin{array}{c}\text { Employment } \\
\text { Growth \% } \\
\text { 2015-2019 }\end{array}$ \\
\hline C & $\begin{array}{l}\text { Manufacturing } \\
\text { industry }\end{array}$ & 62.1 & 13.1 & $51.40 \%$ & 73.49 & 15.19 & $47.30 \%$ \\
\hline G & Wholesale and retail & 47.8 & 12.9 & $73.70 \%$ & 67.79 & 25.42 & $117.30 \%$ \\
\hline $\mathrm{J}$ & $\begin{array}{l}\text { Information and } \\
\text { communications }\end{array}$ & 37.2 & 15.8 & $129.00 \%$ & 91.00 & 40.71 & $203.00 \%$ \\
\hline \multirow[t]{2}{*}{ M } & $\begin{array}{l}\text { Professional, scientific } \\
\text { and technical activities }\end{array}$ & 27 & 7.6 & $90.00 \%$ & 41.13 & 8.9 & $55.40 \%$ \\
\hline & Total general & 50.1 & 12.6 & $74.80 \%$ & 49.66 & 12.33 & $73.13 \%$ \\
\hline
\end{tabular}

Source: the authors based their research on Spanish Ministry of Science and Innovation data [121] and SABI ${ }^{\circledR}$.

\section{Discussion}

Since the 60 s of the 20th century, society has become aware of the impossibility of continuing with the unlimited growth paradigm [48] and the need for a new model [49-51] that takes into account social aspects and respect for the environment [52]. This means that development is no longer evaluated solely on production-growth basis, but that other challenges related to improving the population living conditions, preserving the environment and maintaining natural resources must also be addressed, so that not only short-term, but also long-term effects, are taken into account. The measures carried out in the present must ensure the present population well-being without jeopardizing future generations well-being [52].

This paper focuses on exploring, at the level of firms and, more specifically, SMEs in a limited local environment, to what extent innovation carried out by firms contributes to sustainable development in its three main pillars: economic, social and environmental. Although its application in SMEs is still in its infancy, responsible research and innovation can have a positive economic, social and environmental impact [122].The study carried out with SME in the Valencian Community, it can be started that of a set of 513 companies with 
an "Innovative SME" label awarded by the Spanish Ministry of Science and Technology, $60.62 \%$ of these labels were still currently in force.

Hypothesis 1 refers to the first pillar, economic sustainability, understood as the ability of companies to remain in the market in the long term. The measurement variables in this case were based on the results, from the data provided in the annual accounts of the companies in relation to economic and financial profitability. The analyses confirmed the first hypothesis, the companies with an "Innovative SME" label generated higher economical and financial profitability and were, thus, significantly more economically sustainable, coinciding with the results achieved in other previous works $[83,85,88]$. In other words, innovation is a driver of SME's economical sustainability.

The second hypothesis focuses on social sustainability as measured by the capacity to generate employment, comparing innovative companies with all companies in the region for each sector considered. The results of the analysis lead to the conclusion that the companies with an "Innovative SME" label created proportionally more jobs than SME in general. Based on this premise, innovative firms were more capable of generating employment, which had a stronger impact on the income and welfare of the residents in their area. So, this affirmed that innovation is a driver of social sustainability. These results are consistent with other studies that also find a positive relationship between social sustainability and innovation $[81,83,91]$. Although we have evaluated social sustainability based on the generation of employment, a more in-depth and complete evaluation will require more metrics that allow us to appreciate the company's contribution to the social sustainability of the territory. The employment generation should be completed with analyses that contemplate the employment quality in terms of salary level, degree of stability or temporality. Aspects related to occupational health and employees' satisfaction degree in their jobs should also be included. In addition, it is interesting to take into account the company's policy on gender and social inclusion.

Thirdly, the environmental pillar has been approached from the point of view of environmentally certified companies within the group of innovative companies. Although we know that obtaining certification is not a guarantee that companies innovate in terms of environmental sustainability, the concern for obtaining certification denotes a certain environmental sensitivity. By considering within the set of innovative companies only those with environmental certification and making a comparison with the set of innovative companies by sector, we can assess whether environmental sensitivity has an impact on economic (third hypothesis) and social sustainability (fourth hypothesis). Our studies showed that the third and fourth hypotheses were not fulfilled. Regarding the third hypothesis, which refers to the economical sustainability of the SME with an "Innovative SME" label that also have some indicator showing environmental sensitivity, such as ISO 14001 or its equivalent, the results showed that compared with the total number of companies with an innovative label, the companies that also have environmental sensitivity did not obtain higher economical and financial profitability, but these were, rather, lower, albeit not significantly so.

Regarding the fourth hypothesis, which analyzes the social sustainability of innovative companies with environmental sensitivity compared with innovative companies as a whole. In terms of job creation, no difference was found between SMEs with an innovation label and those that also with environmental indicators. Based on the results obtained in other studies, when innovation and environmental sensitivity and/or orientation are treated together, the results do not coincide [104,105,110-112].

This work has its limitations. Firstly, in the analysis of economic and social sustainability, the economic and financial profitability for the former and the employment generation for the latter for a period of 5 years have been used as metrics. It is considered that, as sustainability is a long-term concept, it would be advisable to carry out these studies for a longer period of time.

Secondly, in the case of social sustainability, it would be necessary to consider additional variables to employment generation, such as contractual conditions, salary levels or 
the workers situation in the company. It would also be interesting to know the measures carried out by the company in aspects related to gender, insertion, training, inclusion and conciliation, participation and health of workers [123,124] and in the supply chain [125]. These aspects will allow us to further analyze the impact of companies on employee and population well-being.

The third constraint relates to environmental sustainability. The companies' contribution to environmental sustainability requires more complex information. Environmentally sustainable innovation can be a response to a variety of factors. The contribution to environmental sustainability can come both from an adaptation to requirements imposed by regulations, cost reduction, and factors originating from adaptation to new market needs versus more environmentally conscious consumer attitudes [126].

Fourthly, it is also necessary to emphasize that the work carried out is limited to a specific and relatively small territory in Spain, so it would be advisable to extend the study territory to other regions or countries.

To conclude with the limitations of the study, it seems appropriate to take a critical look at the aspects of a company that are valued when speaking of its contribution to sustainability. Since the second half of the last century, the concept of development has evolved from focusing exclusively on production growth to becoming aware of the growth limits, the impossibility of infinite production growth, and incorporating aspects related to the population well-being and environmental conservation. It does not seem that this transformation has taken place at the company level. If, from the macro point of view, we have stopped considering development as something linked only to production or economic activity, this paradigm shift will also be necessary at the company level. We should reflect on the aspects that should be taken into account to evaluate the success of a company beyond its generation of economic results [127]. While it is true that many companies currently carry out actions that have an impact on the population well-being, these measures must be compatible with good economic results, i.e., they must be transformed into revenue or cost reduction. Perhaps the company should be valued and rewarded not only for monetary results, something that benefits only the owners, but also for those aspects that have an impact on society, such as quality employment or inclusion and the search for gender equality, issues that, although they do not directly benefit the owners, do benefit society. Years ago, awareness of negative externalities, specifically pollution generated by the companies' activity, was raised as a market failure. In market allocation, the market only takes into account private costs, and by not incorporating external costs, resources are not allocated in the most efficient way for society. Environmental policies aim to internalize these costs so that they reflect the real cost to society. In the case of companies, in general terms, capital, both own and external financing, is directed to those activities that are capable of generating an adequate return, in terms of profit, on invested capital. Companies must pursue this profitability in order to remain in the market. Today, the pursuit of sustainability must be compatible with the achievement of adequate profitability, and it is possible that this contingency limits the speed of pursuit and implementation of actions for sustainability. Just as the paradigm of development has changed, incorporating aspects not related to monetary results, the companies' results could be valued not only by economic results based on profitability as a return on the capital invested by their owners, but also by the results for society that affect the welfare of the population and the conservation of the environment.

\section{Conclusions and Future Research}

Based on the first hypotheses, the companies with an "Innovative SME" label generated higher economical and financial profitability. It can be affirmed that innovative companies are more economically sustainable.

Regarding social sustainability, taking into account that SMEs have greater difficulty in implementing measures aimed at achieving social sustainability than larger companies our study reveals that within SMEs innovative companies have greater capacity to create 
jobs, which means that they more strongly impact the income and welfare of the residents in their area. This confirms our second hypothesis endorsing that innovation is a driver of social sustainability.

Regarding the third hypothesis, the enterprises with an innovation label and which are also environmentally sensitive obtain better results in economical and financial profitability terms; the results obtained from the study indicate that innovative and environmentally sensitive companies are not more economically sustainable. In other words, being environmentally sensitive innovative firms is not an advantage over economical sustainability, we conclude that the third hypothesis is not fulfilled: being environmentally sensitive is not a driver of economic sustainability.

The results of the fourth hypothesis also indicated that, in the group of innovative firms, environmentally sensitive firms do not contribute more to job creation. Thus, we can state that, after innovation has taken place, being environmentally sensitive is not a driver of social sustainability.

Future research should be oriented towards identifying new metrics for assessing economic, social and environmental sustainability, especially the latter two. With regard to social sustainability, information should be gathered on the company's behavior with respect to its employees beyond the generation of employment. In order to be able to conclude in greater depth the contribution to society, the characteristics of the employment generated must be taken into account, both in terms of remuneration and the worker's conditions in the workplace. The contribution to the well-being of the population is also directly related to the measures of insertion and contribution to the reduction of inequalities. As for environmental sustainability, it is necessary to investigate how to delimit and obtain information on all the actions carried out by the company that contribute to environmental conservation. Although we know that environmental certifications do not ensure that companies carry out actions that end up having an impact on environmental sustainability, there are companies that, not having such certification, promote, as consumption habits, actions that do contribute to it, as is the case of many companies related to the collaborative economy. Thus, the actions carried out by companies that contribute to environmental sustainability are an aspect that presents a significant complexity.

In order to clarify the extent to which innovation is a driver for sustainability, future research should delve deeper into actions and strategies carried out by innovative companies, which requires qualitative information complemented by quantitative information. Knowing to what extent companies focus their activity on innovation and what results they achieve from this will also be useful, firstly to identify the difficulties faced by companies and, secondly, to provide useful information for the design of policies and actions aimed at stimulating innovation, taking into account the specific environment in characteristics which the company operates.

Author Contributions: Conceptualization, A.L.-P., G.R.-S. and F.J.F.-S.; methodology, A.L.-P., G.R.-S. and F.J.F.-S.; software, A.L.-P., G.R.-S. and F.J.F.-S.; validation, A.L.-P., G.R.-S. and F.J.F.-S.; formal analysis, A.L.-P., G.R.-S. and F.J.F.-S.; investigation and resources, A.L.-P., G.R.-S. and F.J.F.-S.; data curation, A.L.-P., G.R.-S. and F.J.F.S.; writing—original draft preparation, A.L.-P., G.R.-S. and F.J.F.-S.; writing - review and editing, A.L.-P., G.R.-S. and FJ.F.-S.; visualization, A.L.-P., G.R.-S. and F.J.F.-S. All authors have read and agreed to the published version of the manuscript.

Funding: This research received no external funding.

Institutional Review Board Statement: Not applicable.

Informed Consent Statement: Not applicable.

Data Availability Statement: Not applicable.

Conflicts of Interest: The authors declare no conflict of interest. 


\section{References}

1. Schumpeter, J.A. The Theory of Economic Development; Harvard University Press: Cambridge, MA, USA, $1934 ;$ ISBN 9780674879904.

2. Arjona Torres, M. Dirección Estratégica: Un Enfoque Práctico: Principios y Aplicaciones de la Gestión del Rendimiento; Díaz de Santos: Madrid, Spain, 1999; ISBN 8479783869.

3. Scade, J. Responsabilidad Social y Sostenibilidad Empresarial. Available online: http//www.eoi.es/wiki (accessed on 10 April 2021 ).

4. Srivastava, S.; Sultan, A.; Chashti, N. Influence of innovation competence on firm level competitiveness: An exploratory study. Asia Pac. J. Innov. Entrep. 2017, 11, 63-75. [CrossRef]

5. Freeman, R.E. Strategic Management: A Stakeholder Approach; Cambridge University Press: Cambridge, UK, 1984; ISBN 9780521151740.

6. $\quad$ Drucker, P. The Temptation to Do Good; HarperCollins: London, UK, 1984; ISBN 9780060152536.

7. European Commission SMEs and the Environment in the European Union. Available online: http://ec.europa.eu/enterprise/ policies/sme/business-environment/files/main_report_en.pdf (accessed on 15 April 2021).

8. Suciu (Vodă), A.-D.; Tudor, A.I.M.; Chițu, I.B.; Dovleac, L.; Brătucu, G. IoT Technologies as Instruments for SMEs' Innovation and Sustainable Growth. Sustainability 2021, 13, 6357. [CrossRef]

9. Edeigba, J.; Arasanmi, C. An empirical analysis of SMES' triple bottom line practices. J. Account. Organ. Chang. 2021. ahead-of-print. [CrossRef]

10. Klewitz, J.; Hansen, E.G. Sustainability-oriented innovation of SMEs: A systematic review. J. Clean. Prod. 2014, 65, 57-75. [CrossRef]

11. Walker, B.; Redmon, J.; Sheridan, L.; Wang, C.; Goeft, U. Small and Medium Enterprises and the Environment: Barriers, Drivers, Innovation and Best Practice: A Review of the Literature; Edith Cowan University: Perth, Australia, 2008.

12. European Commission Internal Market, Industry, Entrepreneurship and SMEs. Available online: https:/ / ec.europa.eu/growth/ smes/sme-definition_en (accessed on 20 March 2021).

13. Obi, J.; Ibidunni, A.S.; Tolulope, A.; Olokundun, M.A.; Amaihian, A.B.; Borishade, T.T.; Fred, P. Contribution of small and medium enterprises to economic development: Evidence from a transiting economy. Data Br. 2018, 18, 835-839. [CrossRef]

14. Rius-Sorolla, G.; Maheut, J.; Estelles-Miguel, S.; Garcia-Sabater, J.P. Protocol: Systematic Literature Review on coordination mechanisms for the mathematical programming models in production planning with decentralized decision making. WPOMWorking Pap. Oper. Manag. 2017, 8, 22. [CrossRef]

15. Rosenberg, N. Inside the Black Box; Cambridge University Press: London, UK, 1983; ISBN 9780521248082.

16. Nelson, R.R. Technology, Institutions, and Economic Growth; Harvard University Press: London, UK, 2006; ISBN 978-0674019164.

17. Rosenberg, N. Innovation and Economic Growth. In Innovation and Growth in Tourism; OECD: Lugano, Switzerland, 2006; pp. 43-52. ISBN 9789264025028.

18. Abramovitz, M. Resource and Output Trends in the United States since 1870; National Bureau of Economic Research: Cambridge, MA, USA, 1956; ISBN 0-87014-366-2.

19. Eatwell, J.L.; Solow, R.M. Growth Theory: An Exposition. Econ. J. 1970, 80, 936. [CrossRef]

20. Degong, M.; Ullah, F.; Khattak, M.; Anwar, M. Do International Capabilities and Resources Configure Firm's Sustainable Competitive Performance? Research within Pakistani SMEs. Sustainability 2018, 10, 4298. [CrossRef]

21. OECD Science and Innovation Policy Key Challenges and Opportunities Meeting of the OECD Committee for Scientific and Technological Policy at Ministerial Level. Available online: https://www.oecd.org/science/inno/23706075.pdf (accessed on 1 April 2021).

22. Zerfass, A.; Huck, S. Innovation, Communication, and Leadership: New Developments in Strategic Communication. Int. J. Strateg. Commun. 2007, 1, 107-122. [CrossRef]

23. Christensen, C.M. The Innovator's Solution: Creating and Sustaining Successful Growth; Harvard Business Review Press: Boston, MA, USA, 2013; ISBN 978-1422196571.

24. OECD 2010 Report on Attribution of Profits to Permanent Establishments. Available online: https://www.oecd.org/ctp/transferpricing/45689524.pdf (accessed on 1 April 2021).

25. BCE. BCE-Informe Anual 2017. Available online: https://www.ecb.europa.eu/pub/pdf/annrep/ecb.ar2017.es.pdf (accessed on 9 April 2021).

26. OECD/Eurostat. Oslo Manual 2018; The Measurement of Scientific, Technological and Innovation Activities; OECD: Paris, France, 2018; ISBN 9789264304550.

27. Santandreu Mascarell, C. Propuesta de un Modelo de Gestión de Ideas Adaptado a al las Características Organizativas y de Innovación de las Empresas. El Caso de la Comarca de la Safor; Universitat Politècnica de València: Valencia, Spain, 2012.

28. OECD. European Commission Manual de Oslo Guía para la recogida e interpretación de datos sobre innovación. Available online: https:/ / www.tragsa.es/es/Lists/Publicaciones/attachments/93/ManualdeOslo.pdf (accessed on 10 April 2021).

29. Corma Canós, F. Innovación, Innovadores y Empresa Innovadora; Díaz de Santos: Madrid, Spain, 2013; ISBN 9788499690070.

30. Conca Flor, F.J.; Molina Manchón, H. Innovación Tecnológica y Competitividad Empresarial; Universidad de Alicante: Alicante, Spain, 2000; ISBN 978-84-7908-535-3.

31. Hodges, N.J.; Link, A.N. Innovation by design. Small Bus. Econ. 2019, 52, 395-403. [CrossRef]

32. Fischer, M.M. Innovation, Knowledge Creation and Systems of Innovation. In Innovation, Networks, and Knowledge Spillovers; Springer: Berlin/Heidelberg, Germany, 2006; Volume 35, pp. 169-187. ISBN 978-3-540-35981-4. 
33. Gurrutxaga Abad, A. Condiciones y condicionamientos de la innovación social. Arbor-Cienc. Pensam. Y Cult. 2011, 187, 1045-1064. [CrossRef]

34. Mas, M.; Quesada, J. Las políticas de I+D+i ante la crisis. Rev. Galega Econ. 2010, 19, 1-17.

35. Chen, L.; Qie, K.; Memon, H.; Yesuf, H.M. The Empirical Analysis of Green Innovation for Fashion Brands, Perceived Value and Green Purchase Intention-Mediating and Moderating Effects. Sustainability 2021, 13, 4238. [CrossRef]

36. Kusi-Sarpong, S.; Gupta, H.; Sarkis, J. A supply chain sustainability innovation framework and evaluation methodology. Int. J. Prod. Res. 2019, 57, 1990-2008. [CrossRef]

37. Silvestre, B.S.; Ţî̀rcă, D.M. Innovations for sustainable development: Moving toward a sustainable future. J. Clean. Prod. 2019, 208, 325-332. [CrossRef]

38. Corma Cañós, F. El Canvas de la Innovación; Díaz de Santos: Madrid, Spain, 2017; ISBN 9788490520840.

39. Hatch, N.W.; Mowery, D.C. Process Innovation and Learning by Doing in Semiconductor Manufacturing. Manag. Sci. 1998, 44, 1461-1477. [CrossRef]

40. Reichstein, T.; Salter, A. Investigating the sources of process innovation among UK manufacturing firms. Ind. Corp. Chang. 2006, 15, 653-682. [CrossRef]

41. Keupp, M.M.; Palmié, M.; Gassmann, O. The Strategic Management of Innovation: A Systematic Review and Paths for Future Research. Int. J. Manag. Rev. 2012, 14, 367-390. [CrossRef]

42. Galindo Martín, M.-Á.; Ribeiro, D.; Méndez Picazo, M.T. Innovación y crecimiento económico: Factores que estimulan la innovación. Cuad. Gest. 2012, 12, 51-58. [CrossRef]

43. Oecd Oslo Manual Guidalines for Collecting and Interpreting Innovation Data. Available online: https:/ /ec.europa.eu/eurostat/ documents/3859598/5889925/OSLO-EN.PDF/60a5a2f5-577a-4091-9e09-9fa9e741dcf1?version=1.0 (accessed on 10 April 2021).

44. COTEC Anuario. 2019. Available online: https://content.gnoss.ws/cotec/doclinks/c3/c314/c314a4e9-e89e-4049-aa7b-3b8765a7 f2af/informe-cotec-2019versionweb.pdf (accessed on 10 April 2021).

45. OECD. OECD Science, Technology and Innovation Outlook 2020. Available online: https://www.oecd-ilibrary.org/science-andtechnology /oslo-manual-2018_9789264304604-en (accessed on 9 April 2021).

46. OECD. OECD R\&D Tax Incentive Database. Available online: https:/ / www.oecd.org/sti/B-index.pdf (accessed on 10 April 2021).

47. Purvis, B.; Mao, Y.; Robinson, D. Three pillars of sustainability: In search of conceptual origins. Sustain. Sci. 2019, 14, 681-695. [CrossRef]

48. Meadows, D.H.; Meadows, D.L.; Randers, J.; Behrens, W.W. The Limits to Growth: A Report for the Club of Rome's Project on the Predicament of Mankind; Universe Books: New York, NY, USA, 1972; ISBN 0876631650.

49. Carson, R.L. Silent Spring; Houghton Mifflin: Boston, MA, USA, 1962; ISBN 978-0618249060.

50. Ehrlich, P.R. Population Control or Race to Oblivion? The Population Bomb; Ballantine Book: New York, NY, USA, 1968.

51. Goldsmith, E.; Allen, R.; Allaby, M.; Davoll, J.; Lawrence, S. Blueprint for Survival; Houghton Mifflin: Boston, MA, USA, 1972; ISBN 0395140986

52. Castro, C.J. Sustainable Development. Organ. Environ. 2004, 17, 195-225. [CrossRef]

53. Moldan, B.; Janoušková, S.; Hák, T. How to understand and measure environmental sustainability: Indicators and targets. Ecol. Indic. 2012, 17, 4-13. [CrossRef]

54. Elkington, A.R. Cannibals with Forks: The Triple Bottom Line of 21st Century Business; Capstone Publishing Ltd.: Oxford, UK, 1997; ISBN 1-900961-27-X.

55. Hansmann, R.; Mieg, H.A.; Frischknecht, P. Principal sustainability components: Empirical analysis of synergies between the three pillars of sustainability. Int. J. Sustain. Dev. World Ecol. 2012, 19, 451-459. [CrossRef]

56. Hubbard, G. Measuring organizational performance: Beyond the triple bottom line. Bus. Strateg. Environ. 2009, 18, $177-191$. [CrossRef]

57. Fauzi, H.; Svensson, G.; Rahman, A.A. "Triple Bottom Line" as "Sustainable Corporate Performance": A Proposition for the Future. Sustainability 2010, 2, 1345-1360. [CrossRef]

58. Skouloudis, A.; Evangelinos, K.; Kourmousis, F. Development of an evaluation methodology for triple bottom line reports using international standards on reporting. Environ. Manag. 2009, 44, 298-311. [CrossRef]

59. Rius-Sorolla, G.; Estelles-Miguel, S.; Rueda-Armengot, C. Multivariable Supplier Segmentation in Sustainable Supply Chain Management. Sustainability 2020, 12, 4556. [CrossRef]

60. UN Global Compact Social Sustainability. Available online: https://unglobalcompact.org/what-is-gc/our-work/social (accessed on 29 April 2021).

61. Alyson Warhust Sustainability Indicators and Sustainability Performance Management. Available online: http:/ / pubs.iied.org/ pdfs/G01026.pdf (accessed on 7 June 2021).

62. Comisión Europea Comunicación de la Comisión al Parlamento Europeo, al Consejo, al Comité Económico y Social Europeo y al Comité de las Regiones. Estrategia renovada de la UE para 2011-2014 sobre la responsabilidad social de las empresas. Available online: https:/ / eur-lex.europa.eu/legal-content/ES/TXT/PDF/?uri=CELEX:52011DC0681\&from=ES (accessed on 10 April 2021).

63. Testa, F.; Boiral, O.; Iraldo, F. Internalization of Environmental Practices and Institutional Complexity: Can Stakeholders Pressures Encourage Greenwashing? J. Bus. Ethics 2018, 147, 287-307. [CrossRef]

64. Buhr, N.; Gray, R. Environmental Management, Measurement, and Accounting: Information for Decision and Control? Oxford University Press: Oxford, UK, 2011; ISBN 9780191735318. 
65. EMAS EU Eco-Management and Audit Scheme. Available online: https://ec.europa.eu/environment/emas/index_en.htm (accessed on 7 April 2021).

66. SAC Higg Index. Available online: https:/ / apparelcoalition.org/the-higg-index/ (accessed on 4 April 2021).

67. Radhakrishnan, S. The Sustainable Apparel Coalition and the Higg Index. In Roadmap to Sustainable Textiles and Clothing; Springer: Singapore, 2015; pp. 23-57.

68. Lab., B. El Movimiento B Corp. Available online: https://bcorporation.eu/about-b-lab/country-partner/spain (accessed on 4 April 2021).

69. Shields, J.F.; Shelleman, J.M. A Method to Launch Sustainability Reporting in SMEs: The B Corp Impact Assessment Framework. J. Strateg. Innov. Sustain. 2017, 12, 10-19. [CrossRef]

70. Oeko-tex OEKO-TEX. Available online: https://www.oeko-tex.com/en/ (accessed on 6 April 2021).

71. ISSOP Fundación Energía e Innovación Sostenible Sin Obsolescencia Programada. Available online: https://feniss.org/ (accessed on 6 April 2021).

72. Rivera, J.L.; Lallmahomed, A. Environmental implications of planned obsolescence and product lifetime: A literature review. Int J. Sustain. Eng. 2016, 9, 119-129. [CrossRef]

73. Ferro, C.; Padin, C.; Svensson, G.; Sosa Varela, J.C.; Wagner, B.; Høgevold, N.M. Validating a framework of stakeholders in connection to business sustainability efforts in supply chains. J. Bus. Ind. Mark. 2017, 32, 124-137. [CrossRef]

74. Widya-Hasuti, A.; Mardani, A.; Streimikiene, D.; Sharifara, A.; Cavallaro, F. The role of process innovation between firm-specific capabilities and sustainable innovation in SMEs: Empirical evidence from Indonesia. Sustainability 2018, 10, 2244. [CrossRef]

75. Strobel, N.; Kratzer, J. Obstacles to innovation for SMEs: Evidence from Germany. Int. J. Innov. Manag. 2017, 21, 1750030. [CrossRef]

76. Rius-Sorolla, G.; Maheut, J.; Estelles-Miguel, S.; Garcia-Sabater, J.P.; Jesús Muñoz-Torres, M.; Aviles-Palacios, C. Collaborative Distributed Planning with Asymmetric Information. A Technological Driver for Sustainable Development. Sustainability 2021, $13,6628$. [CrossRef]

77. Del Brío, J.Á.; Junquera, B. A review of the literature on environmental innovation management in SMEs: Implications for public policies. Technovation 2003, 23, 939-948. [CrossRef]

78. Shi, H.; Peng, S.Z.; Liu, Y.; Zhong, P. Barriers to the implementation of cleaner production in Chinese SMEs: Government, industry and expert stakeholders' perspectives. J. Clean. Prod. 2008, 16, 842-852. [CrossRef]

79. Garcia, S.; Cintra, Y.; Rita de Cássia, S.R.; Lima, F.G. Corporate sustainability management: A proposed multi-criteria model to support balanced decision-making. J. Clean. Prod. 2016, 136, 181-196. [CrossRef]

80. Belyaeva, Z.; Rudawska, E.D.; Lopatkova, Y. Sustainable business model in food and beverage industry-A case of Western and Central and Eastern European countries. Br. Food J. 2020, 122, 1573-1592. [CrossRef]

81. Corsi, C.; Prencipe, A.; Capriotti, A. Linking organizational innovation, firm growth and firm size. Manag. Res. J. Iberoam. Acad. Manag. 2019, 17, 24-49. [CrossRef]

82. Montégu, J.P.; Calvo, C.; Pertuze, J.A. Competition, R\&D and innovation in Chilean firm. Manag. Res. J. Iberoam. Acad. Manag. 2019, 17, 379-403. [CrossRef]

83. Del Campo, M.O.; Miguéns-Refojo, V.; Ferreiro-Seoane, F.J. Business Survival and the Influence of Innovation on Entrepreneurs in Business Incubators. Sustainability 2020, 12, 6197. [CrossRef]

84. Cárdenas Gutiérrez, K.M.; Blanco López, L.Y.; Correa Barros, L.F. La Innovación y Tecnología en las Pequeñas y Medianas Empresas Agroindustriales del Departamento del Magdalena; Universidad Cooperativa de Colombia, Facultad de Ciencias Económicas, Administrativas y Contables, Administración de Empresas: Santa Marta/Medellín, Colombia, 2020.

85. Fernández-Portillo, A.; Sánchez-Escobedo, M.C.; Almodóvar-González, M. Análisis del impacto de la innovación, las TIC y el clima empresarial sobre los ingresos de las PYMES. Rev. Int. Organ. 2020, 24, 183-209. [CrossRef]

86. Villegas, R.M. Innovación, creatividad y desarrollo tecnológico en las PyMES de Río Gallegos, Santa Cruz. Rev. Cienc. Empres. Soc. 2021, 3, 1-14.

87. Cuevas-Vargas, H.; Parga-Montoya, N.; Estrada, S. Incidencia de la innovación en marketing en el rendimiento empresarial: Una aplicación basada en modelamiento con ecuaciones estructurales. Estud. Gerenciales 2020, 36, 66-79. [CrossRef]

88. Mashavira, N.; Chipunza, C.; Dzansi, D.Y. Managerial interpersonal competencies and the performance of family-and nonfamily-owned small and medium-sized enterprises in zimbabwe and South Africa. S. Afr. J. Child. Educ. 2019, 17, 1-15. [CrossRef]

89. Martinez-Conesa, I.; Soto-Acosta, P.; Palacios-Manzano, M. Corporate social responsibility and its effect on innovation and firm performance: An empirical research in SMEs. J. Clean. Prod. 2017, 142, 2374-2383. [CrossRef]

90. Aguilar-Fernández, M.E.; Otegi-Olaso, J.R. Firm size and the business model for sustainable innovation. Sustainability 2018, $10,785$. [CrossRef]

91. Adomako, S. Environmental collaboration, sustainable innovation, and small and medium-sized enterprise growth in sub-Saharan Africa: Evidence from Ghana. Sustain. Dev. 2020, 28, 1609-1619. [CrossRef]

92. Dvouletý, O.; Blažková, I. The impact of public grants on firm-level productivity: Findings from the Czech food industry. Sustainability 2019, 11, 552. [CrossRef]

93. Erken, H.; Donselaar, P.; Thurik, R. Total factor productivity and the role of entrepreneurship. J. Technol. Transf. 2018, 43, 1493-1521. [CrossRef] 
94. Caputo, F.; Carrubbo, L.; Sarno, D. The Influence of Cognitive Dimensions on the Consumer-SME Relationship: A SustainabilityOriented View. Sustainability 2018, 10, 3238. [CrossRef]

95. Jin, S.H.; Choi, S.O. The effect of innovation capability on business performance: A focus on it and business service companies. Sustainability 2019, 11, 5246. [CrossRef]

96. Villena-Manzanares, F. El impacto del compromiso por la calidad y la cultura emprendedora sobre el comportamiento innovador de la pyme manufacturera bajo un enfoque de dirección participativa. Dir. Organ. 2016, 58, 4-15. [CrossRef]

97. Uhlaner, L.M.; Berent-Braun, M.M.; Jeurissen, R.J.M.; de Wit, G. Beyond Size: Predicting Engagement in Environmental Management Practices of Dutch SMEs. J. Bus. Ethics 2012, 109, 411-429. [CrossRef]

98. Yu, G.J.; Kwon, K.M.; Lee, J.; Jung, H. Exploration and exploitation as antecedents of environmental performance: The moderating effect of technological dynamism and firm size. Sustainability 2016, 8, 200. [CrossRef]

99. Bouncken, R.B.; Fredrich, V. Business model innovation in alliances: Successful configurations. J. Bus. Res. 2016, 69, 3584-3590. [CrossRef]

100. Kowalska, M. Sme managers' perceptions of sustainable marketing mix in different socioeconomic conditions-A comparative analysis of sri lanka and poland. Sustainability 2020, 12, 659. [CrossRef]

101. Kim, M.; Kim, J.; Sawng, Y.; Lim, K. Impacts of innovation type SME's R\&D capability on patent and new product development. Asia Pac. J. Innov. Entrep. 2018, 12, 45-61. [CrossRef]

102. Romijn, H.; Albaladejo, M. Determinants of innovation capability in small electronics and software firms in southeast England. Res. Policy 2002, 31, 1053-1067. [CrossRef]

103. Rita, D.I.G.; Ferreira, F.A.F.; Meidutè-Kavaliauskienė, I.; Govindan, K.; Ferreira, J.J.M. Proposal of a green index for small and medium-sized enterprises: A multiple criteria group decision-making approach. J. Clean. Prod. 2018, 196, 985-996. [CrossRef]

104. Fadly, D. Greening industry in Vietnam: Environmental management standards and resource efficiency in SMEs. Sustainability 2020, 12, 7455. [CrossRef]

105. Shahedul Quader, M.; Kamal, M.M.; Hassan, A.B.M.E. Sustainability of positive relationship between environmental performance and profitability of SMEs. J. Enterp. Communities People Places Glob. Econ. 2016, 10, 138-163. [CrossRef]

106. Maas, S.; Reniers, G. Development of a CSR model for practice: Connecting five inherent areas of sustainable business. J. Clean. Prod. 2014, 64, 104-114. [CrossRef]

107. Ferrón Vílchez, V. The dark side of ISO 14001: The symbolic environmental behavior. Eur. Res. Manag. Bus. Econ. 2017, 23, 33-39. [CrossRef]

108. De Oliveira, J.A.; Oliveira, O.J.; Ometto, A.R.; Ferraudo, A.S.; Salgado, M.H. Environmental Management System ISO 14001 factors for promoting the adoption of Cleaner Production practices. J. Clean. Prod. 2016, 133, 1384-1394. [CrossRef]

109. Graafland, J. Does Corporate Social Responsibility Put Reputation at Risk by Inviting Activist Targeting? An Empirical Test among European SMEs. Corp. Soc. Responsib. Environ. Manag. 2018, 25, 1-13. [CrossRef]

110. Sánchez-Medina, P.S.; Corbett, J.; Toledo-López, A. Environmental innovation and sustainability in small handicraft businesses in Mexico. Sustainability 2011, 3, 984-1002. [CrossRef]

111. Wysocki, J. Innovative Green Initiatives in the Manufacturing SME Sector in Poland. Sustainability 2021, 13, 2386. [CrossRef]

112. Aguilera-Caracuel, J.; Ortiz-de-Mandojana, N. Green Innovation and Financial Performance. Organ. Environ. 2013, 26, 365-385. [CrossRef]

113. De Pacheco, D.A.J.; ten Caten, C.S.; Jung, C.F.; Ribeiro, J.L.D.; Navas, H.V.G.; Cruz-Machado, V.A. Eco-innovation determinants in manufacturing SMEs: Systematic review and research directions. J. Clean. Prod. 2017, 142, 2277-2287. [CrossRef]

114. Stiglitz, J.E.; Lin, J.Y.; Monga, C. Introduction: The Rejuvenation of Industrial Policy. In The Industrial Policy Revolution I; Palgrave Macmillan: London, UK, 2013; pp. 1-15. [CrossRef]

115. Fagerberg, J. Mobilizing innovation for sustainability transitions: A comment on transformative innovation policy. Res. Policy 2018, 47, 1568-1576. [CrossRef]

116. Lesakova, L'. Small and medium enterprises and eco-innovations: Empirical study of Slovak SME's. Mark. Manag. Innov. 2019, 6718, 89-97. [CrossRef]

117. Cagno, E.; Trianni, A. Exploring drivers for energy efficiency within small- and medium-sized enterprises: First evidences from Italian manufacturing enterprises. Appl. Energy 2013, 104, 276-285. [CrossRef]

118. Kim, H.; Kim, E. How an open innovation strategy for commercialization affects the firm performance of Korean healthcare IT SMEs. Sustainability 2018, 10, 2476. [CrossRef]

119. AIREF Crecimiento Interanual del PIB por CCAA: 2019 T4. Available online: https://www.airef.es/wp-content/uploads/2020 /02/METCAP/2020-02-04-PIB_CCAA_2019_T4-3-de-febrero-2020.pdf (accessed on 1 April 2021).

120. INE Encuesta de Población Activa EPA. Available online: https://www.ine.es/dyngs/INEbase/es/operacion.htm?c=Estadistica_ C\&cid=1254736176918\&menu=ultiDatos\&idp=1254735976595 (accessed on 1 April 2021).

121. Ministerio de Ciencia e Innovación Pymes Innovadoras. Available online: https://www.ciencia.gob.es/portal/site/MICINN/ menuitem.6f2062042f6a5bc43b3f6810d14041a0/?vgnextoid=45cc94d74dd4a410VgnVCM1000001d04140aRCRD (accessed on 28 December 2020).

122. Gonzales-Gemio, C.; Cruz-Cázares, C.; Parmentier, M.J. Responsible Innovation in SMEs: A Systematic Literature Review for a Conceptual Model. Sustainability 2020, 12, 10232. [CrossRef] 
123. Staniškienè, E.; Stankevičiūtè, Ž. Social sustainability measurement framework: The case of employee perspective in a CSRcommitted organisation. J. Clean. Prod. 2018, 188, 708-719. [CrossRef]

124. Amrutha, V.N.; Geetha, S.N. A systematic review on green human resource management: Implications for social sustainability. J. Clean. Prod. 2020, 247, 119131. [CrossRef]

125. Govindan, K.; Shaw, M.; Majumdar, A. Social sustainability tensions in multi-tier supply chain: A systematic literature review towards conceptual framework development. J. Clean. Prod. 2021, 279, 123075. [CrossRef]

126. Brem, A.; Puente-Díaz, R. Creativity, Innovation, Sustainability: A Conceptual Model for Future Research Efforts. Sustainability 2020, 12, 3139. [CrossRef]

127. Jackson, T.; Victor, P.A. Confronting inequality in the "new normal": Hyper-capitalism, proto-socialism, and post-pandemic recovery. Sustain. Dev. 2021, 29, 504-516. [CrossRef] 